\title{
Geological Carbon Dioxide Storage in Mexico: A First Approximation
}

\author{
Oscar Jiménez, Moisés Dávila, Vicente Arévalo, \\ Erik Medina and Reyna Castro \\ Comisión Federal de Electricidad \\ México
}

\section{Introduction}

Carbon dioxide $\left(\mathrm{CO}_{2}\right)$ is one of the industrial gases that contribute to the greenhouse gas (GHG) effect. During the last decades, the emissions of $\mathrm{CO}_{2}$ due to human activity have increased significantly all over the world. There are different and important efforts to reduce or stabilize the concentrations of greenhouse gases in the atmosphere, such as improvements in the efficiency of power plants and the development of renewable energies. However, those approaches cannot deliver the level of emissions reduction needed, especially against a growing demand for energy that promotes economic growth and prosperity. Carbon capture and storage (CCS) approach encompasses the processes of capture and storage of $\mathrm{CO}_{2}$ that would otherwise reside in the atmosphere for long periods of time. Among the different carbon capture and storage options currently in progress all over the world, the geological storage option is defined as the placement of $\mathrm{CO}_{2}$ into an underground repository in such a way that it will remain permanently stored. Mexico is one of the countries which are signatories of different international treaties which call for stabilization of atmospheric gases emissions at a level that prevent anthropogenic interference with the world's regional climates. In Mexico $\mathrm{CO}_{2}$ represents almost $70 \%$ of the total greenhouse gases emissions where the primary sources of $\mathrm{CO}_{2}$ are the burning of fossil fuels for power generation. CCS is a technological approach that holds great promise in reducing atmospheric $\mathrm{CO}_{2}$ concentrations in Mexico. This is the first coordinated assessment of carbon storage potential across the country.

\subsection{Geographical location of Mexico}

Mexico is a country located in the southern portion of North America, and is bordered to the north by the United States, to the southeast by Guatemala, Belize and the Caribbean Sea, to the west and south by the Pacific Ocean, and to the east by the Gulf of Mexico (Figure 1). The country's total area is about 1972550 square kilometers.

\subsection{Previous work}

With the aim of searching for places where to store carbon dioxide, Mexico was subdivided into three exclusion zones and four inclusion zones [1](Figure 2). The exclusion zones are zones A, B and G. Zone A is composed by igneous rocks with high seismic and volcanic hazard, 
and is not recommended for storage. Zone B encompasses also igneous rocks with less seismic and volcanic hazards than zone $\mathrm{A}$, but not yet recommended for $\mathrm{CO}_{2}$ storage. The zone $\mathrm{G}$ is a marine zone of exclusion comprising the ocean floor, deep marine sediments and high seismic and tectonic hazardous processes in the Pacific Ocean.

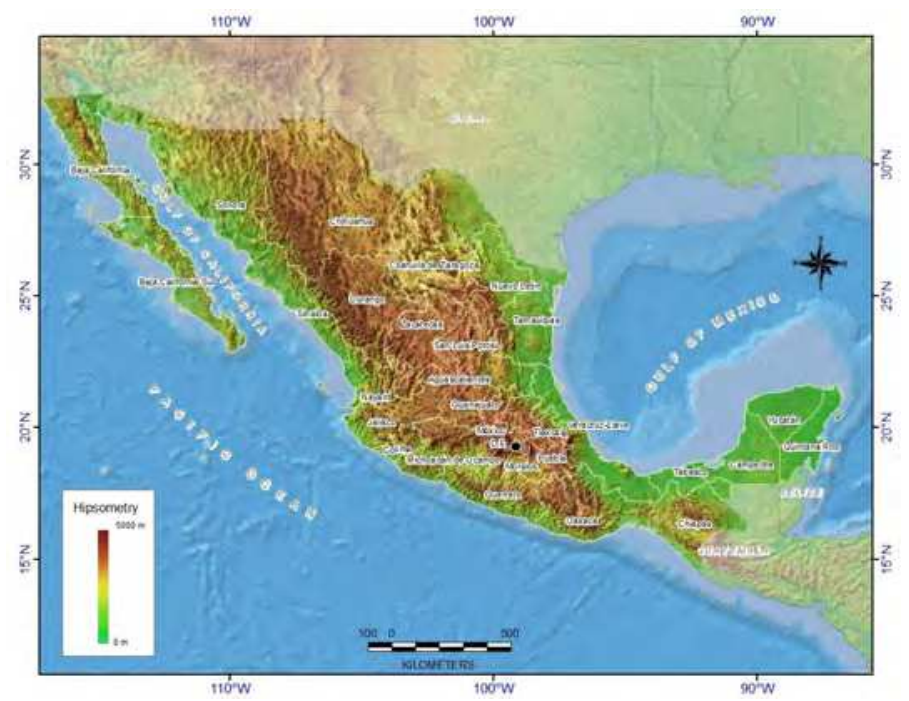

Fig. 1. Hypsographic map of Mexico displaying federal states divisions and countries' borderlines.

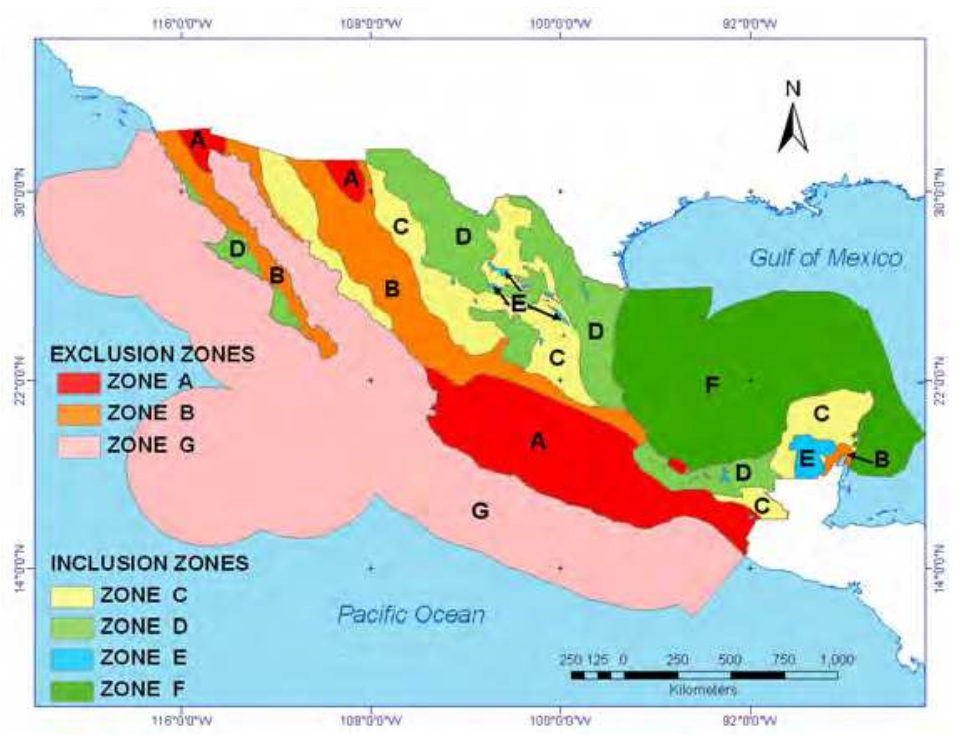

Fig. 2. Exclusion and inclusion zones for geologic $\mathrm{CO}_{2}$ storage in Mexico. After [1]. 
The inclusion zones are zones C, D, E and F. Zone C represents terrigenous geological formations and mainly carbonate sedimentary rocks cropping out in the area. Zone $\mathrm{D}$ includes terrigenous as well as carbonate sedimentary rocks sequences. Zone $\mathrm{E}$ is composed of evaporitic deposits and associated sedimentary rocks. And zone F reflects sediments deposited in the marine continental shelf, slope and deep waters beneath the Gulf of Mexico. All of these zones were outlined taking into account surficial lithological features, large geological subsurface structures and recent volcanic and tectonic activity in a country scale assessment. The exclusion zones were not recommended for geologic carbon storage due to its high seismic, geothermic and active volcanic hazardous potential. On the contrary, the inclusion zones yielded the best $\mathrm{CO}_{2}$ storage potential and were recommended for further detailed studies in order to find geological provinces with a good CCS capacity.

\subsection{Purpose and scope}

The purpose of this chapter is to present the analysis of different geological provinces to address the possibility of storing anthropogenic $\mathrm{CO}_{2}$ in deep underground geologic formations, particularly in eastern continental Mexico. Up to now, the assessment has been focused on five geological provinces in order to evaluate and quantify theoretically its $\mathrm{CO}_{2}$ storage potential and to identify prospective regions and/or sectors that should form the object of further and detailed studies.

The analysis has been considered in relation to a specific type of storage, that is, deep saline aquifers and to the location of the stationary $\mathrm{CO}_{2}$ sources currently available for the whole nation. It must be noted though that an assessment of $\mathrm{CO}_{2}$ storage potential is surrounded by large uncertainties, which increase in number with the lack of available data and detailed information. The proposed work in this chapter recognizes this uncertainty, and the envisaged output is an overview of possible scenarios rather than the quantification of specific areas or sites for CCS. The aim is to provide a high level summary of $\mathrm{CO}_{2}$ geologic storage potential across Mexico where the capacity resource estimates presented are intended to be used as an initial assessment of potential geologic storage prior to a local area selection. It is expected that as new subsurface data and a more refined methodology are acquired, the CCS studies will be improved in the near future.

\subsection{Methodology}

The total CCS process is frequently analyzed from several viewpoints which include very wide technological, economic and environmental issues. Some of the issues are well constrained while others are poorly understood. In the particular case of $\mathrm{CO}_{2}$ storage potential there are also various aspects involved, such as the separation and capture of $\mathrm{CO}_{2}$ at the point of emission, the mass of $\mathrm{CO}_{2}$ emitted by the point of emission, the infrastructure and transportation of $\mathrm{CO}_{2}$, and the storage of $\mathrm{CO}_{2}$ in deep underground geologic formations [2]. However, here we are only concerned with the types of $\mathrm{CO}_{2}$ emission sources, the searching of suitable geologic reservoir rock sequences and their location, and the quantification of the theoretical capacity of storing a given volume or mass of $\mathrm{CO}_{2}$ in selected sectors across Mexico. This pragmatic methodology was based on the public domain accessible data and present-day geological knowledge, and it does not incorporate geological constraints in the theoretical capacity estimations, nor does it incorporate risk factors, environmental hazards, solubility and mineral trapping of $\mathrm{CO}_{2}$, or quantification of injectivity of the potential storage rock sequences. 
The first phase included a survey of $\mathrm{CO}_{2}$ points of emission, production information, source category, emissions factors, and annual $\mathrm{CO}_{2}$ emissions that were obtained from the mexican Pollutant Release and Transfer Inventory (RETC by its Spanish acronym) and the Ministry of the Environment and Natural Resources (SEMARNAT, by its Spanish acronym) databases $[3,4]$. These databases consider the stationary sources. A compilation for the United Nations Framework Convention on Climate Change (UNFCCC) [4] includes the stationary and the non-stationary source emissions. The non-stationary source emissions such as those that come from the transportation sector, the change of land use and forestry, and some others like landfills were excluded from the analysis. The $\mathrm{CO}_{2}$ stationary sources included power plants, oil and natural gas processing facilities, cement plants, agricultural processing facilities, iron and steel production facilities, and other industry processing facilities. The spatial location of the stationary $\mathrm{CO}_{2}$ emission sources were calculated and compiled through different mapping tools that contain latitude and longitude information for various Mexican locations. The analysis of $\mathrm{CO}_{2}$ stationary sources was done to provide reliable emission estimations, identify major $\mathrm{CO}_{2}$ emission sources within each region, and to asses the applicability of the data in subsequently infrastructure analyses.

The second phase consisted of the identification of geological storage provinces through the careful analysis and screening of available geological data. In this regard, there are different proposed methodologies that are similar $[5,6,7,8,9,27]$. Only minor differences are evident depending upon the used weights that show the relative importance of the criteria. Therefore, our selection of candidate storage provinces was according to the basin level of the assessment scale [10] (Figure 3). This "basin scale" exploration assessment required a little more local data categories and a better level of detail than the "country scale".

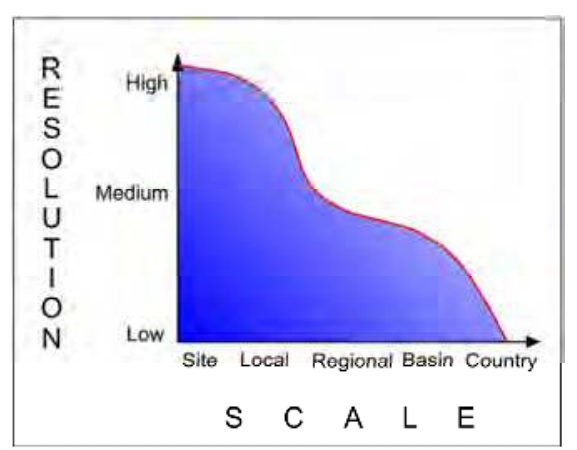

Fig. 3. Data and assessment scales for CCS geological screening studies. After [10].

In this "basin scale" assessment, both terms, basin and province, are considered synonyms. The term basin has different meanings depending upon geologic features of the region, such as geothermal regime, size, age, boundaries, type and thickness of sedimentary fill, geologic deformation, tectonic context, and many others parameters that can change with time [11, $12,13,14]$. However, these variable geologic features are also possible to be applied to the meaning of the term province.

The assessment was focused on the previously identified inclusion zone. Within the inclusion zone, twelve provinces were defined taking into consideration the types of geomorphological developments, stratigraphic successions, major structural deformation patterns, homogeneous tectonic history, and known subsurface geological boundaries 
between all of them (Figure 4). Actually, their outlined boundaries are very similar with those of the petroleum basins previously named for those areas of Mexico [15, 16, 17, 18, 19]. From the twelve established provinces, at the moment, only five of them were considered to be studied in greater detail to estimate the geological resource for storing $\mathrm{CO}_{2}$. These provinces are: Burgos, Tampico-Misantla, Veracruz, Sureste and Yucatan, all of them located in the continental and marine platform areas along Gulf of Mexico.

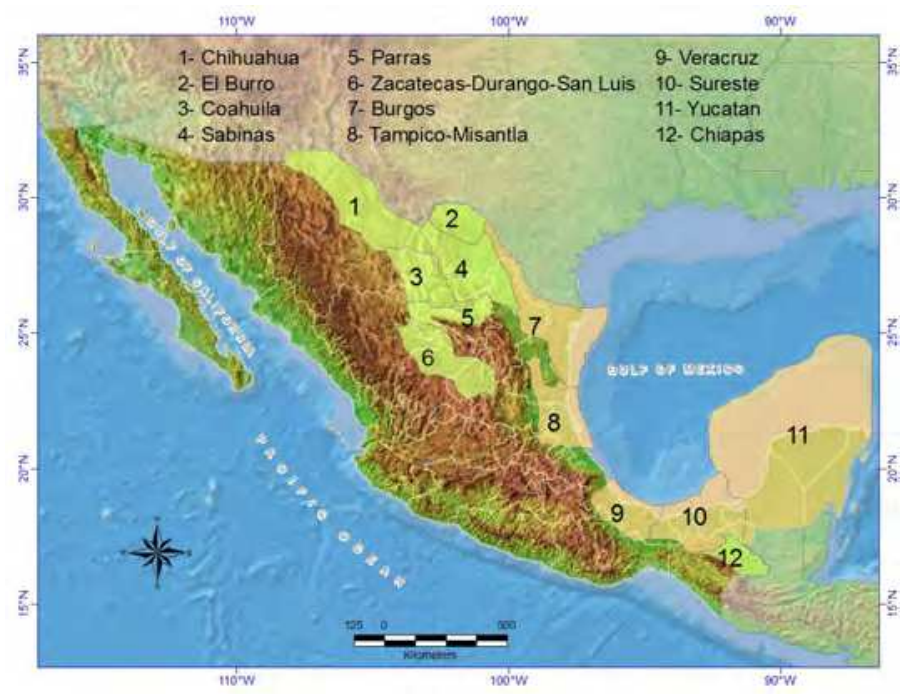

Fig. 4. Mexican geological provinces identified according to their underground potential for $\mathrm{CO}_{2}$ storage.

The screening and selection of the provinces was based on the published geologic maps from a scale of 1:250,000 to 1:4,000,000 and reports about surface geology, stratigraphic and structural features, regional geologic cross-sections $(50-200 \mathrm{~km}$ in length and $500 \mathrm{~m}$ to $3 \mathrm{~km}$ in thickness), geophysical information and available public oil well data within each province. Three main groups of sedimentary formations for underground geologic carbon storage were observed. These groups of sedimentary formations are referred to as carbonate, evaporite and terrigenous sequences depending upon the main, respectively, carbonated, evaporitic and clastic content of the rock units. It is worth to mention that the stratigraphic uncertainty is high since the specific subsurface geologic information is quantitatively scarce and sometimes restricted and/or no detailed.

Otherwise, the disposal of $\mathrm{CO}_{2}$ in geological formations, generally, includes unmineable coal seams, oil and gas reservoirs, and deep saline reservoirs. In Mexico unmineable coal areas are not considered as a CCS option because they are located inside the exclusion zone, that is, they are affected seismo-tectonically and located close to the surface. On the contrary, the oil and gas reservoirs are the best option, particularly the EOR (Enhanced Oil Recovery) technique in the exhausted oil fields. But, at the moment, this prospect is ruled out due to the inaccessibility to the public domain of the oil databases and information. Only PEMEX (Petróleos Mexicanos) the oil governmental industry could carry out such studies. So, based on the fact that subsurface layers of porous rocks are generally saturated 
with brine and that they form deep saline aquifers characterized by high concentrations of dissolved salts and unsuitable for agriculture or human consumption, they were envisaged as the favorable option for $\mathrm{CO}_{2}$ storage in Mexico. The storing $\mathrm{CO}_{2}$ in saline formations is achievable since there are examples from such projects [20,21].

The third phase dealt with the estimation of theoretical capacity within each identified geological province. At present, various calculation methods have been proposed to know the storage capacity of a rock formation $[22,10,23,20,24,25,2]$. They have been applied to different country projects within their respective areas and still there is uncertainty. The reasons for this uncertainty are diverse but they broadly comprise key aspects such as financial support, CCS technology research and development, and a real partnership between country organizations and academic teams [26, 28].

The concept of storage capacity was referred to a completely free phase of the $\mathrm{CO}_{2}$, which means without taking into account the $\mathrm{CO}_{2}$ reaction with the walls of the reservoirs or formations. It is considered only the volume of $\mathrm{CO}_{2}$ that can be retained in the available porous space of the storage formation or reservoir at depths between 800 and 2500 meters. At such depths the $\mathrm{CO}_{2}$ has some properties like a gas and some like a liquid due to the changes in temperature and pressure conditions [64]. These are known as the $\mathrm{CO}_{2}$ supercritical conditions or the critical point of the $\mathrm{CO}_{2}$. The huge advantage of storing $\mathrm{CO}_{2}$ in the supercritical condition is that the required storage volume is much less if the $\mathrm{CO}_{2}$ were at standard pressure conditions.

For the estimation of the theoretical capacity of storing $\mathrm{CO}_{2}$, it was used an approach here called "parameterization". The parameterization refers to observations, deductions, and calculations derived from the physical parameters obtained from geological maps, regional stratigraphic and structural cross-sections, and well data from the public petroleum industry. Different geological variables were taken into account since the estimation was done with respect to general storage capacity resources and following the standards used in the petroleum industry, that is, stratigraphic and structural traps, as well as seal (cap) rocks that play a decisive role within any geological province.

One first step in the parameterization approach was the determination of important geological features that would fulfill the storage requirements such as structural or stratigraphic trap, seal formation, stratigraphic discontinuities, geological faults, depth conditions, appropriate porosity and thickness of the target sedimentary sequence. The critical features were: reservoir depth (more than $800 \mathrm{~m}$ and less than $2500 \mathrm{~m}$ ), thickness, porosity, lithological composition (predominantly carbonates and clastic deposits) and, for effects of the volume calculation, the relationship between "net thickness" versus "total thickness". All of this, with the goal of having an expression figure of the fraction of the geological formation susceptible to become a reservoir. The previous information had to be homogeneously similar within the area with a radius between 10 and 20 kilometers around each oil well considered and the nature of trap boundaries. When the information was assumed to be minimally sufficient and it was valued as an attractive target from the point of view of the depth, thickness, porosity, and permeability, then it was selected to quantify its potential capacity to become a $\mathrm{CO}_{2}$ storing sector. Otherwise, the portion of the regional section including the wells was discarded.

One second step of the approach was the direct application of an equation whose variables were fulfilled with the information above mentioned for deep saline aquifers. Therefore, the critical parameters obtained in the previous step were substituted in the formula proposed by Bachu et al in 2007 [10]: 


$$
\mathrm{VCO}_{2} \mathrm{t}=\mathrm{V} \varphi\left(1-\mathrm{S}_{\text {wirr }}\right) \Xi \operatorname{Ah} \varphi\left(1-\mathrm{S}_{\text {wirr }}\right)
$$

Where $\mathrm{A}$ is the trap area, $\mathrm{h}$ is the average thickness, $\mathrm{VCO}_{2} \mathrm{t}$ is the theoretical volume available, $\varphi$ is the effective porosity, $\mathrm{V}$ is the volume and $S_{\text {wirr }}$ is the irreducible water saturation. The solving of the equation yielded the theoretical storage capacity volume of the sector under consideration.

\section{Estimated $\mathrm{CO}_{2}$ emissions from stationary sources}

The most recent update on the mexican national inventory (SEMARNAT) was compiled in 2006 (UNFCCC)[4]. This document shows that the total annual GHG in Mexico are above 709 million metric tons (Mt) of $\mathrm{CO}_{2}$ equivalent. The carbon dioxide represents $69.5 \%$ out of a total of $492 \mathrm{Mt}$ of emissions from stationary and non-stationary sources. There were estimated $285 \mathrm{Mt}$ of $\mathrm{CO}_{2}$ emissions from stationary sources (Figure 5).

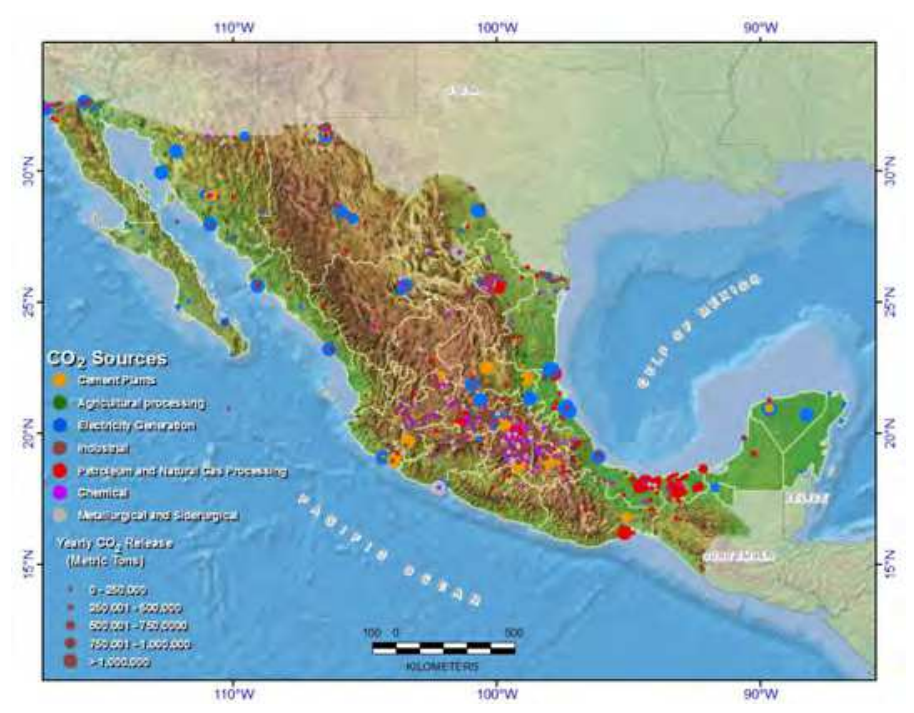

Fig. 5. Main $\mathrm{CO}_{2}$ stationary source emissions in Mexico. Each colored dot represents a different type of stationary source by category. Dot size represents the relative magnitude of $\mathrm{CO}_{2}$ emissions released per year.

In addition, RETC data shows approximately $216 \mathrm{Mt}$ of $\mathrm{CO}_{2}$ emitted from 1,860 stationary sources, according to the different industrial and economic activities in Mexico (Table 1).

From the above data it is evident that the electricity supplier sector is the most important contributor to $\mathrm{CO}_{2}$ emissions from stationary sources. It releases to the atmosphere $107 \mathrm{Mt}$ of $\mathrm{CO}_{2}$, roughly $50 \%$ of the total. It includes emissions from the Federal Commission for Electricity (CFE, by its Spanish acronym) which is the national public service agency, as well as from private small electricity suppliers companies. The oil \& petrochemicals facilities add another $22 \%$ and, therefore, the whole energy sector is responsible for $72 \%$ (154 Mt) of $\mathrm{CO}_{2}$ emissions in the country. The cement, metallurgical, iron \& steel industries are also major contributors to the overall $\mathrm{CO}_{2}$ country emissions, though they are smaller in comparison to the energy industry. In fact, the electricity production industry is the largest contributor, 
and it does from a small number of stationary sources (Figure 6). The industrial and chemical sectors show a much larger number of identified sources, but the relative share of their $\mathrm{CO}_{2}$ emissions, compared to those of the energy sector, is lower.

\begin{tabular}{|c|c|c|}
\hline SECTOR & $\mathrm{CO}_{2}$ EMISSIONS (metric tons) & No. OF SOURCES \\
\hline Electricity Generation & 107351754 & 113 \\
\hline Oil \& Petrochemical & 47556986 & 273 \\
\hline Cement & 26016726 & 60 \\
\hline Metallurgical, Iron \& Steel & 21367965 & 261 \\
\hline Industrial & 8764815 & 709 \\
\hline Chemical & 4027475 & 438 \\
\hline Agriculture Processing & 735319 & 6 \\
\hline TOTAL & 215821040 & 1860 \\
\hline
\end{tabular}

Table 1. Estimations of $\mathrm{CO}_{2}$ emissions from stationary sources by sectors. The point sources only include facilities that were reported via the Annual Certificate of Operation (COA, by its Spanish acronym) to RETC, managed by SEMARNAT [3].
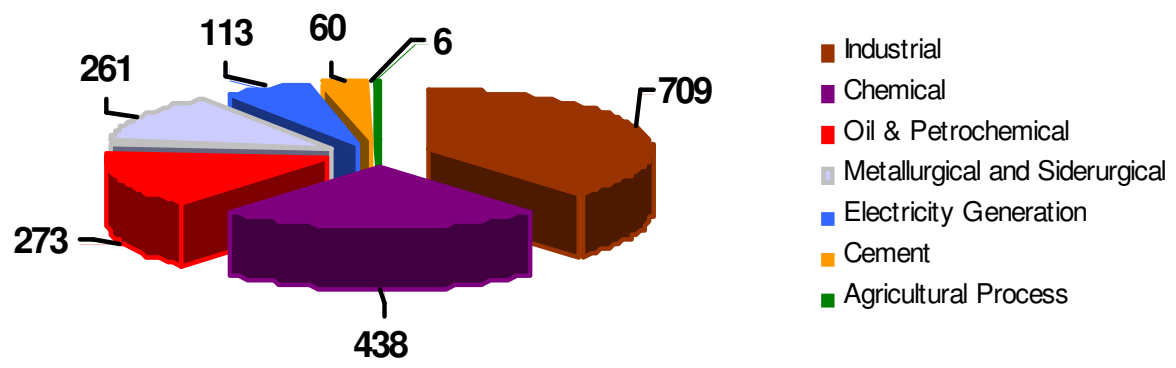

Fig. 6. Number of reported emissions from stationary sources by sector.

From the geographical point of view, the areas with higher $\mathrm{CO}_{2}$ emissions are located in the northeastern portion of Mexico and in the ferderal states around the Gulf of Mexico. The state of Coahuila tops the list with more than $23 \mathrm{Mt}$ of $\mathrm{CO}_{2}$ released per year (Table 2). This is mostly due to the deployed coal-fired power plants and metallurgical, iron and steel facilities. The states of Nuevo León and Tamaulipas release approximately $25 \mathrm{Mt} n$ of $\mathrm{CO}_{2}$ that come from a scattered high number of source points. In the southeastern part, the states of Veracruz and Campeche together attain almost $40 \mathrm{Mt}$ of $\mathrm{CO}_{2}$.

In this context, it is advisable to apply CCS technologies in such industries, since on the one hand, the fewer number of stationary sources with a high level of $\mathrm{CO}_{2}$ emissions, the better the opportunity to deploy $\mathrm{CO}_{2}$ capture, injection and storage facilities. On the other, the scenario leads to an economic feasibility projects particularly at the Gulf Costal region where power generation plants, oil \& petrochemical, industrial and chemical facilities share the large $\mathrm{CO}_{2}$ emissions. 


\begin{tabular}{|c|c|c|}
\hline STATE & $\begin{array}{l}\mathrm{CO}_{2} \text { EMISSIONS } \\
\text { (metric tons/year) }\end{array}$ & SOURCES \\
\hline Coahuila & 23219675 & 66 \\
\hline Campeche & 21946705 & 25 \\
\hline Veracruz & 17962809 & 80 \\
\hline Hidalgo & 16362111 & 46 \\
\hline San Luis Potosí & 13580498 & 42 \\
\hline Nuevo León & 12725855 & 145 \\
\hline Tamaulipas & 12554901 & 123 \\
\hline Sonora & 9596070 & 46 \\
\hline Michoacán & 9568763 & 35 \\
\hline México & 9286971 & 284 \\
\hline Chihuahua & 8016227 & 265 \\
\hline Guerrero & 7286999 & 4 \\
\hline Colima & 7040064 & 11 \\
\hline Guanajuato & 5751629 & 62 \\
\hline Tabasco & 5676613 & 67 \\
\hline Baja California & 4672787 & 34 \\
\hline Yucatán & 4214110 & 13 \\
\hline Oaxaca & 4108894 & 9 \\
\hline Puebla & 3982865 & 53 \\
\hline Querétaro & 3466122 & 67 \\
\hline Jalisco & 3301123 & 87 \\
\hline Sinaloa & 3079872 & 11 \\
\hline Durango & 2961072 & 18 \\
\hline Morelos & 1805748 & 18 \\
\hline Baja California Sur & 959132 & 9 \\
\hline Aguascalientes & 799295 & 32 \\
\hline Distrito Federal & 746588 & 123 \\
\hline Chiapas & 732172 & 26 \\
\hline Tlaxcala & 203851 & 43 \\
\hline Quintana Roo & 136962 & 8 \\
\hline Zacatecas & 74555 & 7 \\
\hline Nayarit & 2 & 1 \\
\hline TOTAL & 215821040 & 1860 \\
\hline
\end{tabular}

Table 2. Estimated $\mathrm{CO}_{2}$ emissions by mexican state and number of point sources. 


\section{Geologic $\mathrm{CO}_{2}$ storage potential}

In order to estimate the $\mathrm{CO}_{2}$ storage potential and to identify different sectors that should be the object of detailed assessment five geological provinces were analyzed. From north to south the geological provinces are: Burgos, Tampico-Misantla, Veracruz, Sureste and Yucatan (Figure 7).

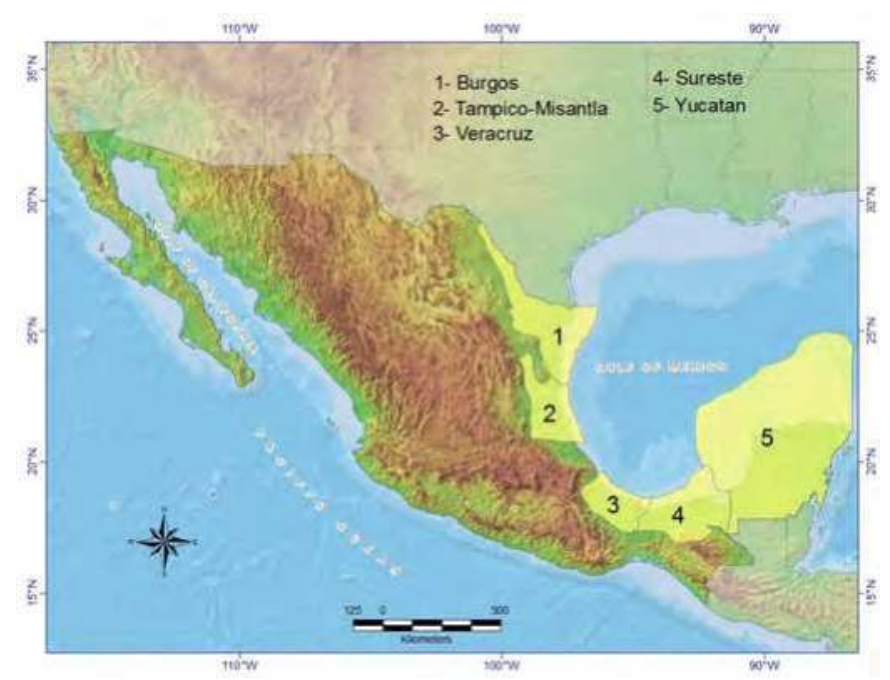

Fig. 7. Mexican geological provinces assessed for underground $\mathrm{CO}_{2}$ storage.

\subsection{Burgos province}

The Burgos province is located at the most northeastern portion of Mexico. This province is bordered to the north by the United States (sharing the Rio Bravo along the borderline), to the east by the Gulf of Mexico, to the south by Tampico-Misantla province, and to the west by the first exposures that form the contact between Cretaceous and Tertiary rocks [29].

The basement of the geologic province consists of metamorphic and intrusive igneous rocks $[30,31]$. However, the basement geometry and its age distribution have not been well established. On top of the basement, a sedimentary evaporitic and carbonated sequence was accumulated in Mesozoic times [50, 62]. After a period of regional subsidence a thick sequence of mainly coarse to fine grained sediments was deposited starting in the Tertiary and continuing into the Quaternary.

According to the geological analysis it is documented the existence of a thick terrigenous sequence composed by interbedded conglomerates, sandstones and shales of Cenozoic age [32]. These sequences have frequent lateral facies changes and abundant lenticular sand bodies which were deposited mainly in deltaic, shelf and deep marine environments. Exposures of these rock units extend from the Eocene to Quaternary (Figure 8).

Regional geological sections B1, B2, B3 and B4 were studied to estimate the $\mathrm{CO}_{2}$ storage capacity on the continental portion on the Burgos province. All of them document similar stratigraphic units and characteristic sets of faults as a result of both extensional tectonic and sedimentological events [36]. Section B4 has no public subsurface geological information available, consequently, it was not considered during the assessment process. 


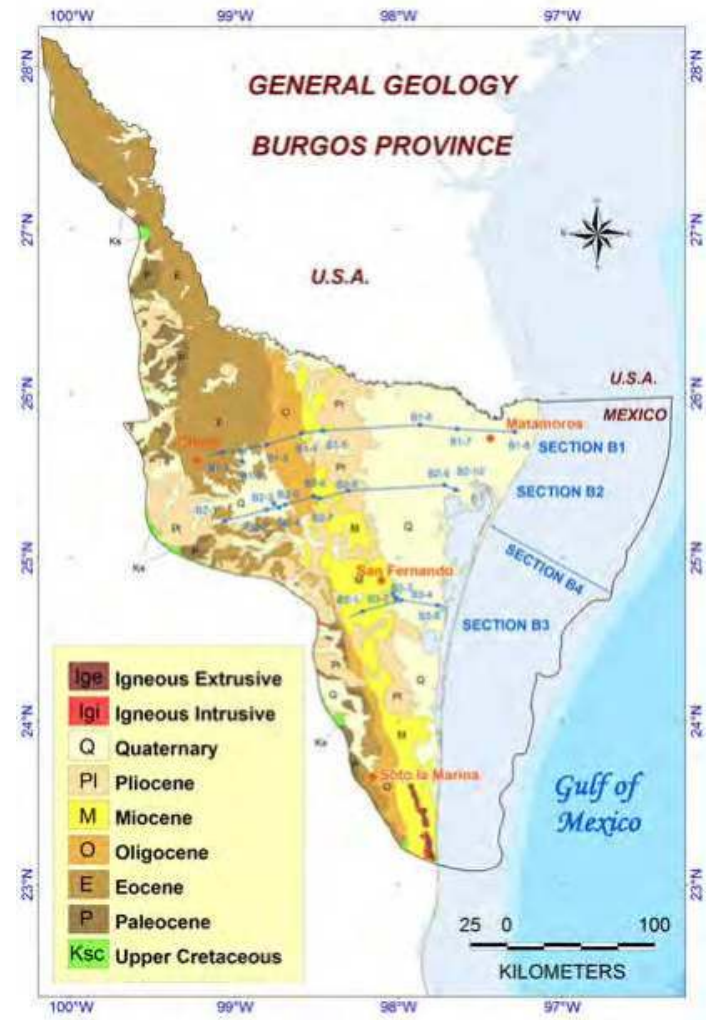

Fig. 8. Simplified geology map of Burgos province depicting geological sections and wells. After $[29,33,34,35,46]$.

As all the sections depict similar stratigraphic and structural features, only Section B2 is presented (Figure 9). The section B2 has approximately $150 \mathrm{~km}$ in length and show a basement covered by slightly deformed Jurassic and Cretaceous rocks sequences. On top of it, there is a thick tertiary sedimentary and faulted sequence of rocks. The sedimentary sequence and the fault system reveal a chronological pattern from older formations and faults on the west to younger ones on the east. Across the entire section are evident the Eocene and Oligocene rocks on the west, and Miocene formations on the east.

According to the type of stratigraphical or structural trap and the lithological and petrophysical features obtained from the oil wells several extrapolations were performed along the regional geological sections in order to select the best potential sectors where saline formations could become $\mathrm{CO}_{2}$ reservoirs.

An example of detailed description of sector B2-4 of section B2 is presented (Figure 10). The sector B2-4 displays an Eocene terrigenous sequence that is located at approximately 1500 meters depth and consists of thick bedded homogeneous sandstone layers with crossstratification and minor amounts of intercalated, laterally discontinuous, thin bedded shale. The thickness of the unit is 880 meters but the important fraction is 0.6, therefore the considered net thickness is about 528 meters. The unit is part of a structural trap in a "roll- 
over" anticline with a seal composed of shale from the upper limit of same sequence. The Oligocene sedimentary sequence overlies the Eocene sequence and consists of a siltstone and shale that are interpreted as a seal cap-rock.

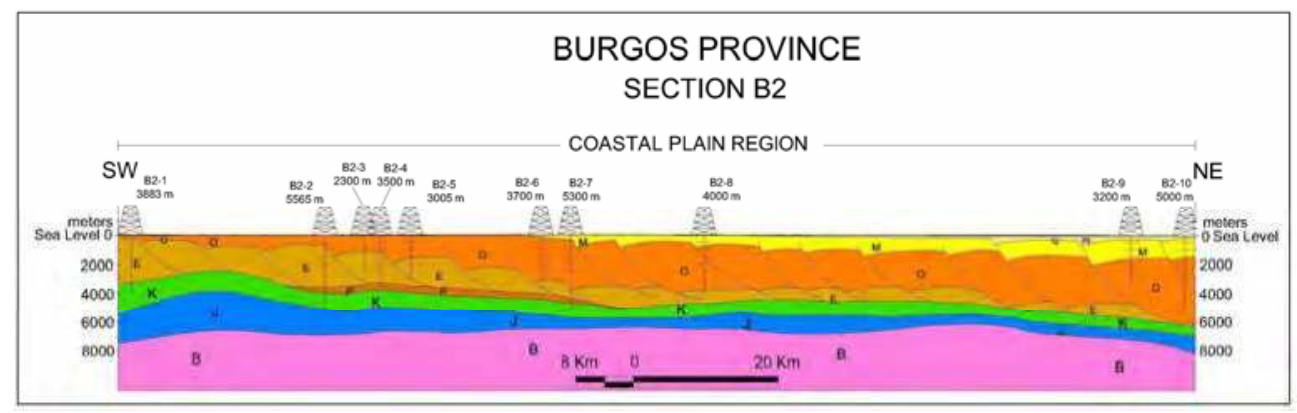

Fig. 9. Regional cross section B2. Across the section both the age of the rock units and the structural deformation are evident from west to east. B: Basement, J: Jurassic, K: Cretaceous, P: Paleocene, E: Eocene, O: Oligocene, M: Miocene, Q: Quaternary. After [31, 33, 34 y 35].

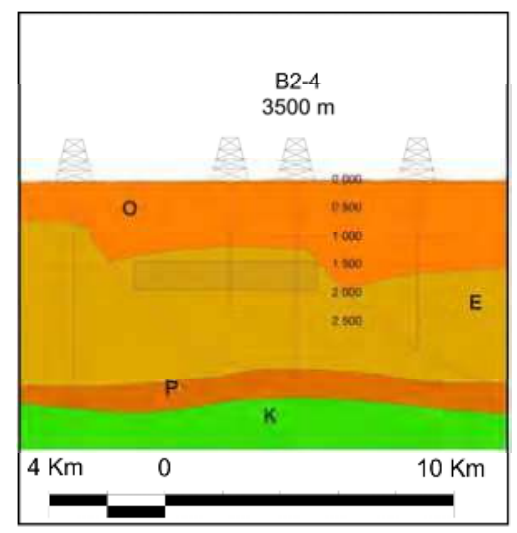

Fig. 10. Sector B2-4 from cross regional section B2. Vertical scale is in meters. K: Cretaceous, P: Paleocene, E: Eocene, O: Oligocene.

The computed petrophysical parameters are porosity 0.1 , irreducible water 0.6 , permeability less than 10 milidarcies $(\mathrm{mD})$, density of CO2 about $675 \mathrm{~kg} / \mathrm{m} 3$. The respected volume of influence is assumed based on the lithological and petrophysical homogeneities of the rock unit supported by the extrapolation of features between oil wells, and the distances imposed by stratigraphical and structural elements. The use of these parameters in the theoretical calculation of the capacity results in 1.36 giga metric tons $(\mathrm{Gt})$ of $\mathrm{CO}_{2}$ for sector B2-4 (Table 3and 4).

The same approach was used in all sections of Burgos province giving 31 potential sectors on terrigenous sequences. Sometimes several sectors are located at the same well area of influence but at different depths. The marine zone was not computerized although several projects at the shallow marine platform in the United States point out the great potential of that zone (Figure 11). 


\begin{tabular}{|r|r|r|r|}
\hline \multicolumn{4}{|c|}{$\mathrm{CO}_{2}$ THEORETICAL STORAGE CAPACITY IN SECTOR B2-4 } \\
\hline Total thickness & & 880 & $\mathrm{~m}$ \\
\hline Net fraction & & 0.6 & $\mathrm{~m}$ \\
\hline Net thickness & & 528 & $\mathrm{~m}$ \\
\hline Cross section length & & 9541 & $\mathrm{~m}$ \\
\hline Length influence & & 10000 & $\mathrm{~m}$ \\
\hline Area & $\mathrm{A}$ & 95410000 & $\mathrm{~m}^{2}$ \\
\hline Volume & $\mathrm{V}$ & 50376480000 & $\mathrm{~m}^{3}$ \\
\hline Porosity & $\Phi$ & 0.1 & \\
\hline Irreducible water saturation & $\mathrm{S}_{\text {wirr }}$ & 0.6 & \\
\hline CO ${ }_{2}$ Density & $\rho_{\mathrm{CO}}$ & 675 & $\mathrm{~kg} / \mathrm{m}^{3}$ \\
\hline Storage capacity in volume unit & $\mathrm{V}_{\mathrm{CO} 2 \mathrm{t}}$ & 2015059200.00 & $\mathrm{~m}^{3} \mathrm{CO}_{2}$ \\
\hline Storage capacity in terms of mass & $\mathrm{MCO}_{2} \mathrm{t}$ & 1.36 & $\mathrm{Gt} \mathrm{CO}_{2}$ \\
\hline & & & \\
\hline
\end{tabular}

Table 3. Theoretical storage capacity at Sector B2-4 in the Burgos province.

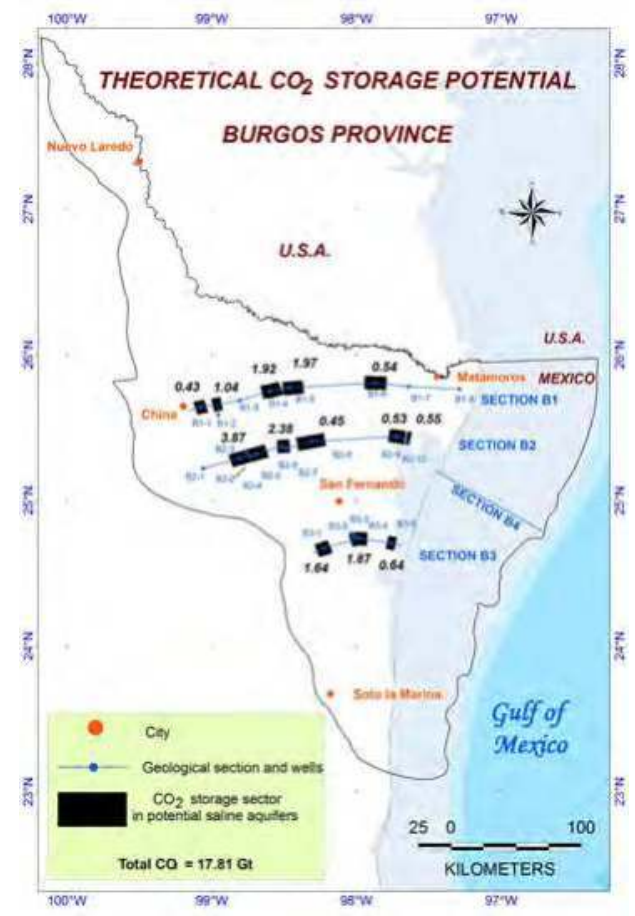

Fig. 11. Burgos province displaying the sectors (in black) of saline aquifers capable of storing $\mathrm{CO}_{2}$. The marine zone was not quantified. 
In summary, according to the geological sections, geological traps, sedimentary sequences and petrophysical parameters obtained from the Burgos province the theoretical capacity corresponds to $17.81 \mathrm{Gt}$ in 31 assessed sectors (Table 4).

\begin{tabular}{|c|c|c|c|c|c|c|c|c|c|c|}
\hline \multicolumn{11}{|c|}{ BURGOS PROVINCE } \\
\hline \multirow{2}{*}{$\begin{array}{l}\text { CROSS } \\
\text { SECT- } \\
\text { ION }\end{array}$} & \multirow[t]{2}{*}{ SECTOR } & \multirow[t]{2}{*}{$\begin{array}{c}\text { TRAP } \\
\left({ }^{*}\right)\end{array}$} & \multirow{2}{*}{\begin{tabular}{|c|} 
TARGET \\
SEQUENCE \\
Terrigenous
\end{tabular}} & \multicolumn{2}{|c|}{ SIZE } & \multicolumn{4}{|c|}{$\begin{array}{c}\text { GENERAL PETROPHYSICAL } \\
\text { PARAMETERS }\end{array}$} & \multirow{2}{*}{$\begin{array}{l}\text { Partial } \\
\text { capacity in } \\
\text { terms of } \\
\text { mass } \\
(G \mathrm{t})\end{array}$} \\
\hline & & & & $\begin{array}{c}\text { Area } \\
\left(10^{6} \mathrm{~m}^{2}\right)\end{array}$ & $\begin{array}{c}\text { Thick- } \\
\text { ness } \\
(\mathrm{m})\end{array}$ & $\begin{array}{c}\text { Ef- } \\
\text { fective } \\
\text { por- } \\
\text { osity } \\
\left(\Phi_{\mathrm{e}}\right) \\
\end{array}$ & $\begin{array}{c}\text { Irreducible } \\
\text { water } \\
\text { saturation } \\
\left(S_{\text {wirr }}\right)\end{array}$ & $\begin{array}{c}\mathrm{CO}_{2} \\
\text { Densi- } \\
\text { ty } \\
(\mathrm{Kg} / \\
\left.\mathrm{m}^{3}\right) \\
\end{array}$ & $\begin{array}{l}\text { Perme- } \\
\text { ability } \\
\text { (mili- } \\
\text { darcies) }\end{array}$ & \\
\hline \multirow[t]{9}{*}{ B1 } & B1-1 & Struct & E1 & 76.5 & 402 & 0.05 & 0.6 & 700 & $<10$ & 0.43 \\
\hline & B1-2 & Struct & $\mathrm{P}$ & 60.5 & 350 & 0.1 & 0.3 & 700 & $<30$ & 1.04 \\
\hline & B1-4 & Struct & E7 & 108.64 & 369.2 & 0.1 & 0.5 & 700 & $<10$ & 1.40 \\
\hline & B1-4 & Both & $\mathrm{O} 1$ & 60.5 & 93.84 & 0.1 & 0.5 & 650 & $<30$ & 0.35 \\
\hline & B1-4 & Both & $\mathrm{O} 2$ & 115.22 & 59 & 0.1 & 0.5 & 500 & $<30$ & 0.17 \\
\hline & B1-5 & Both & $\mathrm{O} 1$ & 117.81 & 376.5 & 0.1 & 0.4 & 700 & $<30$ & 1.86 \\
\hline & B1-5 & Both & $\mathrm{O} 3$ & 140.92 & 13.75 & 0.15 & 0.4 & 650 & $<60$ & 0.11 \\
\hline & B1-6 & Both & $\mathrm{O} 3$ & 150.57 & 26.5 & 0.08 & 0.3 & 700 & $<60$ & 0.16 \\
\hline & B1-6 & Struct & $\mathrm{O} 4$ & 82.96 & 110 & 0.1 & 0.4 & 700 & $<10$ & 0.38 \\
\hline \multirow[t]{15}{*}{ B2 } & B2-2 & Both & E1 & 95.88 & 30 & 0.05 & 0.6 & 700 & $<10$ & 0.04 \\
\hline & B2-2 & Struct & E7 & 77.63 & 97.5 & 0.1 & 0.5 & 600 & $<10$ & 0.23 \\
\hline & B2-4 & Struct & E1 & 95.41 & 528 & 0.1 & 0.6 & 675 & $<10$ & 1.36 \\
\hline & B2-4 & Both & $\mathrm{O} 1$ & 69.7 & 276 & 0.1 & 0.5 & 600 & $<30$ & 0.58 \\
\hline & B2-5 & Both & E1 & 85.06 & 94.5 & 0.15 & 0.6 & 700 & $<10$ & 0.34 \\
\hline & B2-5 & Both & E7 & 67.38 & 16.25 & 0.1 & 0.5 & 700 & $<10$ & 0.04 \\
\hline & B2-5 & Both & $\mathrm{O} 1$ & 82.52 & 458 & 0.1 & 0.5 & 675 & $<30$ & 1.28 \\
\hline & B2-6 & Both & $\mathrm{O} 1$ & 40.68 & 688 & 0.1 & 0.4 & 700 & $<10$ & 1.18 \\
\hline & B2-7 & Both & $\mathrm{O} 1$ & 46.32 & 741.2 & 0.1 & 0.5 & 700 & $<30$ & 1.20 \\
\hline & B2-8 & Both & $\mathrm{O} 2$ & 108.2 & 71.5 & 0.1 & 0.5 & 675 & $<10$ & 0.26 \\
\hline & B2-8 & Both & $\mathrm{O} 3$ & 86.33 & 57.75 & 0.08 & 0.3 & 600 & $<60$ & 0.17 \\
\hline & B2-8 & Struct & $\mathrm{O} 4$ & 67.45 & 10 & 0.1 & 0.4 & 550 & $<10$ & 0.02 \\
\hline & B2-9 & Both & $\mathrm{O} 2$ & 111.12 & 77 & 0.1 & 0.5 & 700 & $<30$ & 0.30 \\
\hline & B2-9 & Struct & $\mathrm{O} 4$ & 57.83 & 97.5 & 0.1 & 0.4 & 690 & $<30$ & 0.23 \\
\hline & B2-10 & Struct & $\mathrm{O} 4$ & 28.42 & 460 & 0.1 & 0.4 & 700 & $<10$ & 0.55 \\
\hline \multirow[t]{7}{*}{ B3 } & B3-1 & Both & $\mathrm{O} 1$ & 78.1 & 312 & 0.1 & 0.4 & 700 & $<30$ & 1.02 \\
\hline & B3-1 & Both & $\mathrm{O} 2$ & 80.91 & 64.4 & 0.1 & 0.5 & 675 & $<10$ & 0.18 \\
\hline & B3-1 & Struct & $\mathrm{O} 4$ & 44.7 & 250 & 0.1 & 0.4 & 650 & $<10$ & 0.44 \\
\hline & B3-2 & Struct & $\mathrm{O} 4$ & 36 & 637.5 & 0.1 & 0.4 & 650 & $<10$ & 0.90 \\
\hline & B3-4 & Both & $\mathrm{O} 2$ & 64.85 & 47 & 0.1 & 0.5 & 700 & $<10$ & 0.11 \\
\hline & B3-4 & Struct & $\mathrm{O} 4$ & 34.56 & 612.5 & 0.1 & 0.4 & 675 & $<10$ & 0.86 \\
\hline & B3-5 & Struct & $\mathrm{O} 4$ & 59.17 & 257.5 & 0.1 & 0.4 & 700 & $<10$ & 0.64 \\
\hline & & & & & & & & & TOTAL & 17.81 \\
\hline
\end{tabular}

Table 4. Theoretical storage capacity of the Burgos province. 


\subsection{Tampico-Misantla province}

The Tampico-Misantla province lies in the central-east portion of Mexico. It is bordered to the north by the Burgos province and the Sierra de Tamaulipas mountain range, to the south by the mountainous fronts of the Sierra Madre Oriental folded-thrust belt and the TransMexican volcanic belt, and to the east by the Gulf of Mexico [29, 37].

The deep basement of the Tampico Misantla province consists of Precambrian and Paleozoic metamorphic and granitic rocks, and faults zones caused by extensional tectonic events some of which dating back to the origin of the Gulf of Mexico [38, 39]. Also, the basement pattern shows tectonic uplifts and through structures of different shapes and sizes. Overlying the basement a thick succession of sedimentary materials have been deposited ranging from Jurassic red beds and evaporites to Cretaceous carbonate sequences originated in shelf, platform and abyssal marine facies. On top of this succession a number of terrigenous sedimentary sequences were deposited concurrently with contractional tectonic events of the Laramide orogeny, since the beginning of the Cenozoic [40]. During Cenozoic times a thick terrigenous package with minor carbonates were accumulated to fulfill the coastal plain and marine regions of the west Gulf of Mexico.

The surficial geology of the province exposes sedimentary rocks in parallel strips that run from the foothills of the Sierra Madre Oriental folded-thrust belt on the west to the existing coastal plain and marine platform regions of the Gulf of Mexico to the east. The older sedimentary rocks can be found on the west while the younger rocks are in the east. Some extrusive igneous rocks crop out on the northern and southern areas of the province (figure 12).

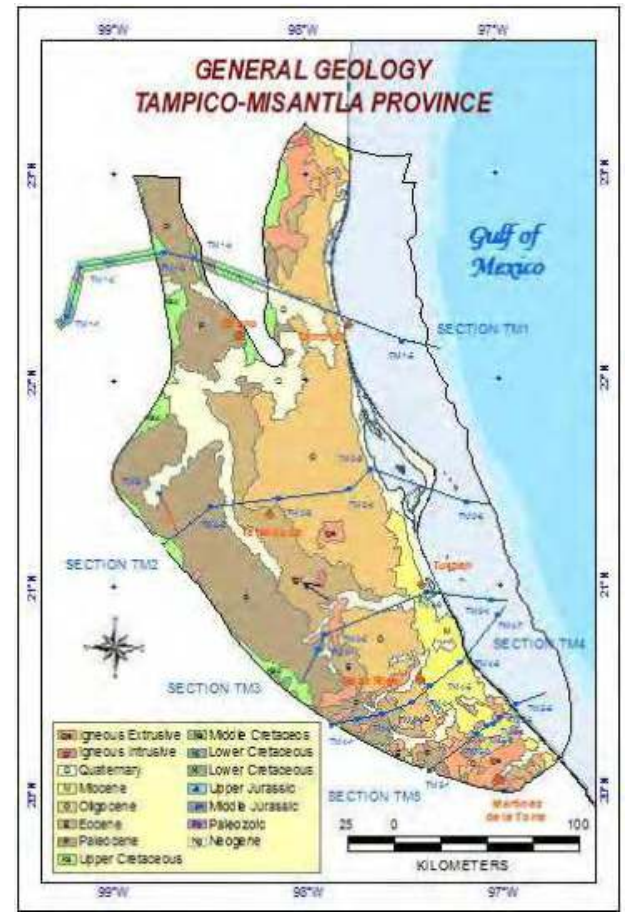

Fig. 12. Simplified geologic map of Tampico-Misantla province displaying regional cross sections and wells. After [33, 34, 35, 37, 46]. 
Five regional geologic cross sections were analyzed to understand the Tampico-Misantla province. Due to the similar geologic patterns showed along all regional sections, only section TM4 is presented. Section TM4 represents approximately $130 \mathrm{~km}$ in length of the subsurface regional geological profile, where basement faults and, horst and graben structures of different sizes are clearly revealed (Figure 13). On the western portion of section TM4 are evident the folded and thrust faulted carbonate sequences of Cretaceous age, and on the eastern side is clear the minor tectonic deformation of the Cretaceous platform carbonates as well as the Cenozoic terrigenous sequences.

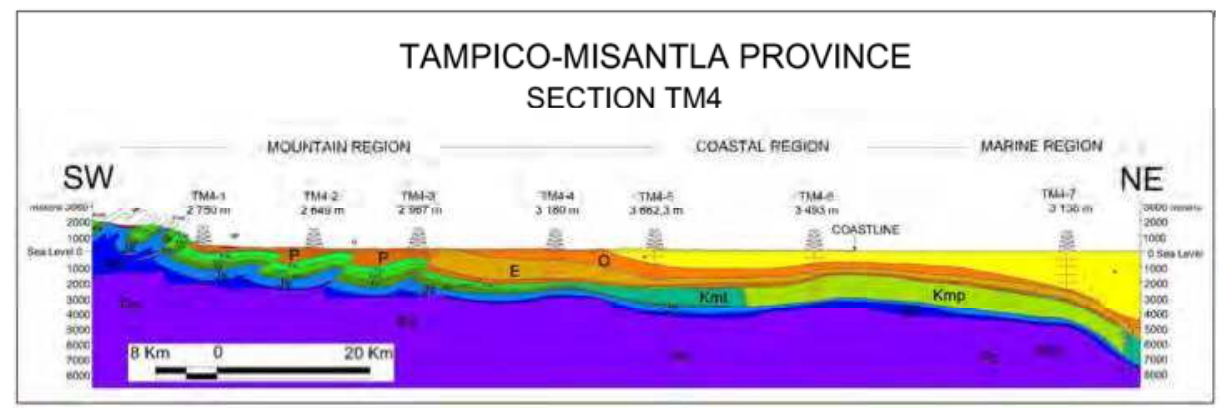

Fig. 13. Regional geologic section TM4. Mesozoic carbonate sequences are strongly deformed on the west side while Mesozoic and Cenozoic sedimentary successions are almost undeformed on the eastern side of the regional section. B: Basement, Jm: Middle Jurassic, Js. Upper Jurassic, Kic: Lower Cretaceous, Kmc: Middle Cretaceous, Ksc: Upper Cretaceous, P: Paleocene, E: Eocene, O: Oligocene, M: Miocene. After [29, 33, 34, 35, 40, 41].

In order to search sectors where saline aquifers could become potential $\mathrm{CO}_{2}$ reservoirs the east sides of the regional sections were preferentially assessed because of their minor tectonic deformation. An example of the performed analysis is presented in sector TM4-6. Sector STM4-6 is located approximately at 2000 meters depth, and is part of carbonate reef platform sequence of Cretaceous age. The rock unit is a 635 meters package of medium to thick bedded light yellow gray fossiliferous limestone slightly deformed as an open anticline. This limestone is overlain by a sequence of thin bedded shale formed in deep basin conditions (Figure 14). The shales is interpreted as a good seal cap rock.

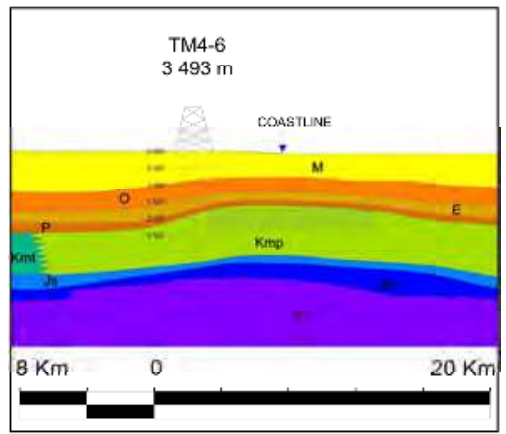

Fig. 14. Sector STM4-6 is overlaying a high basement element. Vertical scale is in meters. Pz: Paleozoic, Jm: Middle Jurassic, Js: Upper Jurassic, Kmt: Middle Cretaceous, Kmp: Middle Cretaceous, P: Paleocene, E: Eocene, O: Oligocene, M: Miocene. 
The petrophysical parameters from sector STM4-6 are porosity $9 \%$, irreducible water less than $30 \%$, net thickness 508 meters, and $\mathrm{CO}_{2}$ density around $693.6 \mathrm{~kg} / \mathrm{m}^{3}$. The use of these parameters in the theoretical calculation has resulted in $1.08 \mathrm{Gt}$ (Table 5).

\begin{tabular}{|c|c|c|c|}
\hline \multicolumn{4}{|c|}{$\mathrm{CO}_{2}$ THEORETICAL STORAGE CAPACITY IN SECTOR TM4-6. } \\
\hline Total thickness & & 635 & $\mathrm{~m}$ \\
\hline Net fraction & & 0.8 & $\mathrm{~m}$ \\
\hline Net thickness & & 508.00 & $\mathrm{~m}$ \\
\hline Cross section length & & 4861.70 & $\mathrm{~m}$ \\
\hline Length influence & & 10000 & $\mathrm{~m}$ \\
\hline Area & $\mathrm{A}$ & 2469743.60 & $\mathrm{~m}^{2}$ \\
\hline Volume & $\mathrm{V}$ & 24697436000 & $\mathrm{~m}^{3}$ \\
\hline Porosity & $\Phi$ & 0.09 & \\
\hline Irreducible water saturation & $\overline{S_{\text {wirr }}}$ & 0.3 & \\
\hline $\mathrm{CO}_{2}$ Density & ${\rho \mathrm{CO}_{2}}$ & 693.6 & $\mathrm{~kg} / \mathrm{m}^{3}$ \\
\hline Storage capacity in volume unit & $\mathrm{V}_{\mathrm{CO} 2 \mathrm{t}}$ & 1555938468.00 & $\mathrm{~m}^{3} \mathrm{CO}_{2}$ \\
\hline Storage capacity in terms of mass & $\mathrm{MCO}_{2} \mathrm{t}$ & 1.08 & $\mathrm{Gt} \mathrm{CO}_{2}$ \\
\hline
\end{tabular}

Table 5. Theoretical storage capacity at Sector STM4-6.

After the analysis of the entire number of regional geological sections the Tampico-Misantla province yield 12 sectors. Four of them correspond to carbonate sequences and eight to terrigenous sequences. The total $\mathrm{CO}_{2}$ capacity estimation corresponds to $9.75 \mathrm{Gt}$ (Figure 15 and Table 6).

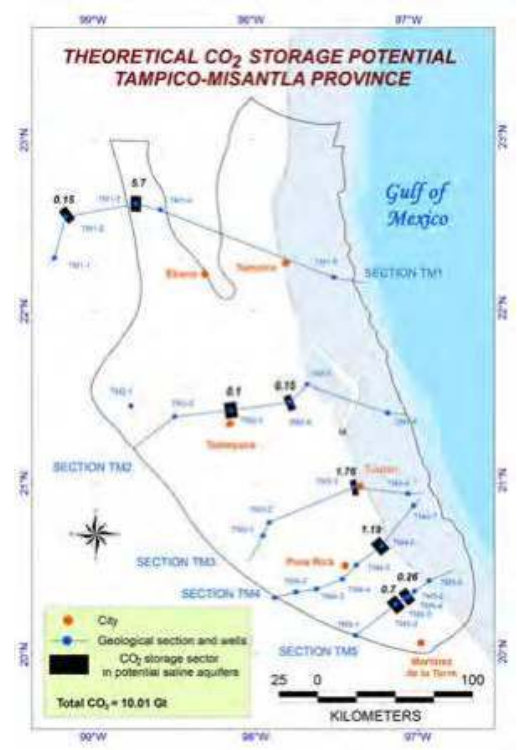

Fig. 15. Tampico-Misantla province showing sectors of potential saline aquifers capable of storing $\mathrm{CO} 2$ (in black). 


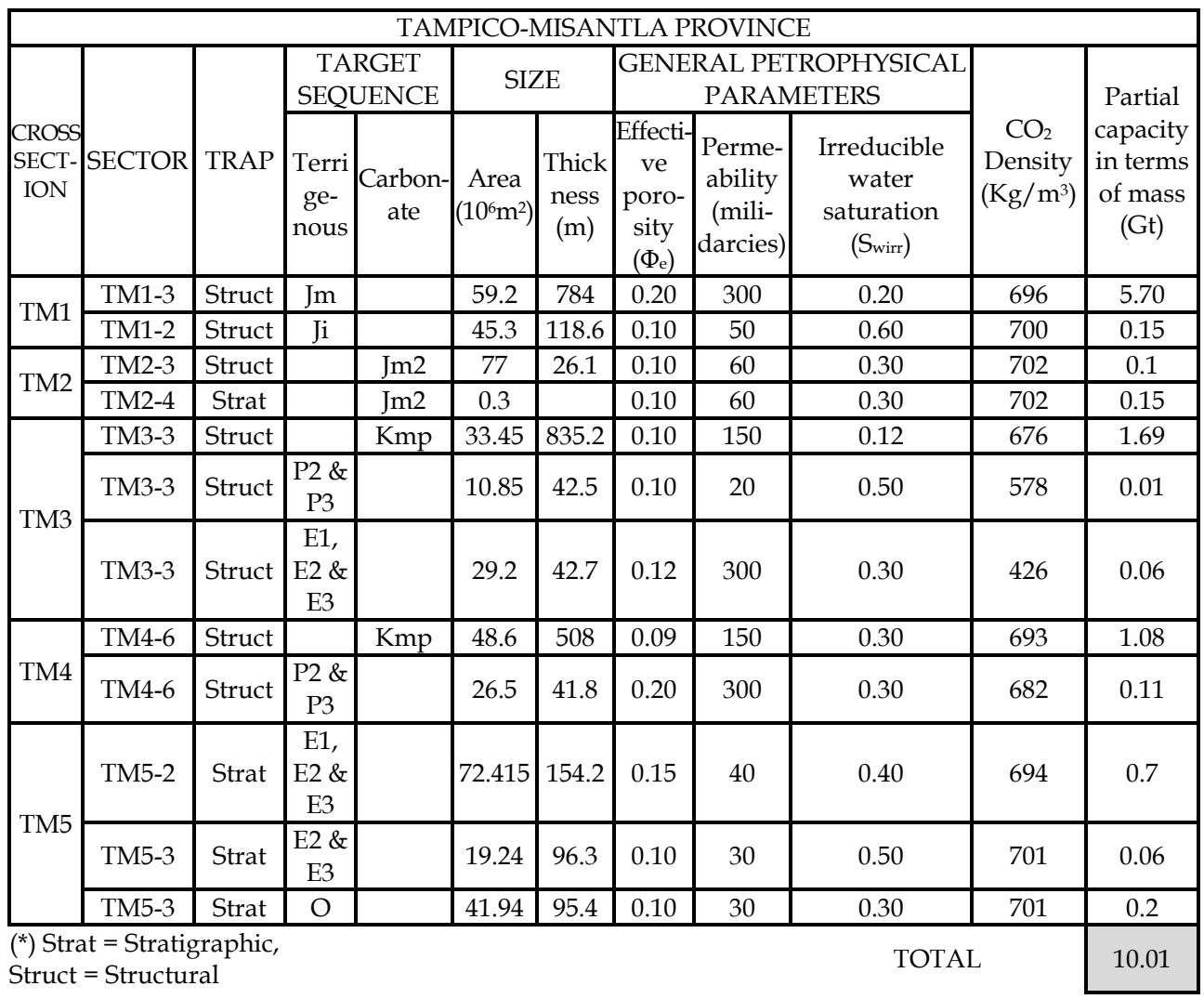

Table 6. Theoretical storage capacity of the Tampico-Misantla province.

\subsection{Veracruz province}

Veracruz province lies to the east of Mexico, sitting in the central part of the state of Veracruz. This province is bounded to the north by the Trans-Mexican volcanic belt, to the southeast by Los Tuxtlas volcanic field complex, to the west by Sierra Madre Oriental folded-thrust belt (known in this area as Sierra de Zongolica), and to the east-northeast by the Gulf of Mexico [42, 43]. The current geological context suggests a quick subsidence process along with several tectonic deformational events since Mesozoic times. The surficial geology suggests a faster subsidence process at the north of the province (Figure 16).

Six geologic sections were analyzed in order to estimate theoretical $\mathrm{CO}_{2}$ potential capacity for this province. From the subsurface point of view, the Veracruz province can be clearly divided into two geologic subprovinces. The first subprovince is the Sierra Madre Oriental folded-thrust belt and its continuation at depth known as the "Frente Tectonico Sepultado" (Buried Tectonic Front). It is characterized by folded calcareous rocks deformed by reverse faulting. The second subprovince is known as "Cuenca Terciaria de Veracruz" (Veracruz Tertiary Basin) composed by a thick succession of interbedded shale, siltstone, sandstone and conglomerate [40, 42, 47]. This terrigenous sequence has been, in turn, affected tectonically in distinctive styles and at different depths. 


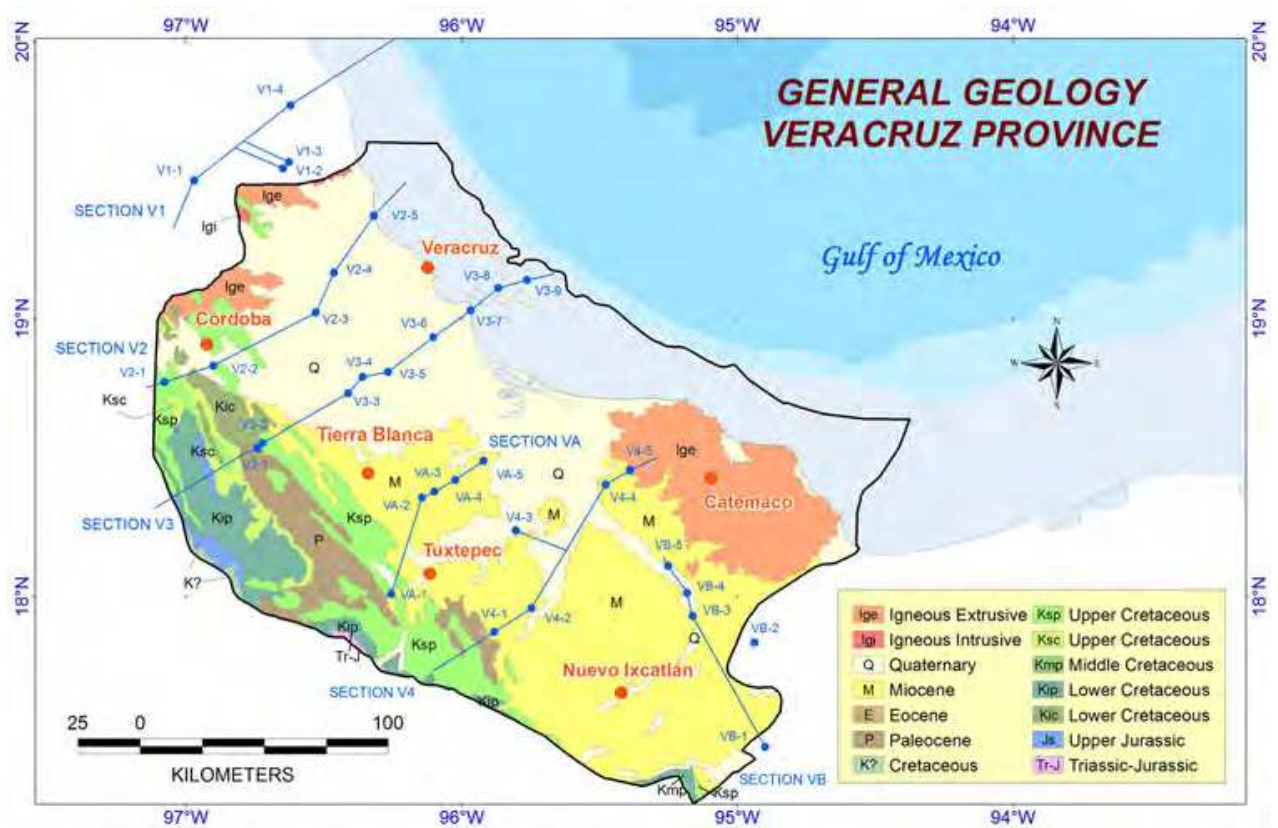

Fig. 16. Simplified geologic map of the Veracruz province, and location of regional geologic sections and wells. After [43, 33, 34, 35, 46].

For reference, figure 17 shows one of the regional sections that display structural features customarily found in the area. Section V3, about $180 \mathrm{~km}$ in length, lies in the middle of Veracruz province. The western half of the section displays calcareous sequences highly deformed by reverse faulting [42]. These sequences reveal Cretaceous facies from platform to basin environments. The eastern half of the section reflects terrigenous sequences wherein Paleocene and Eocene units expose reverse faulting folds.

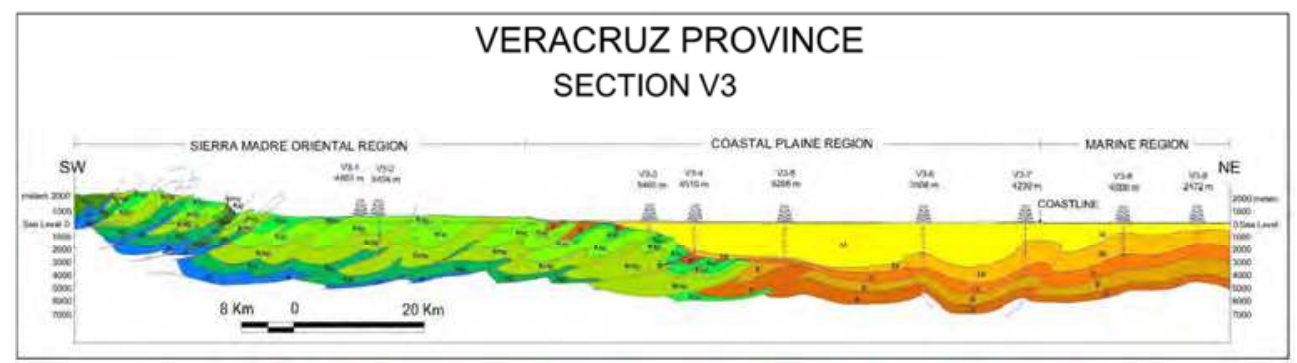

Fig. 17. Regional geological section V3. The left hand side of the regional section shows Zongolica range's Cretaceous carbonate reverse faults as well as the buried tectonic front. The opposite side reveals early Cenozoic deformed terrigenous sequences and late Cenozoic undeformed sedimentary materials. Js: Upper Jurassic, Kip: Lower Cretaceous, Kmp: Middle Cretaceous, Ksp: Upper Cretaceous, Ksc: Upper Cretaceous, P: Paleocene, E: Eocene, O: Oligocene, Mi: Lower Miocene, M: Miocene, Q: Quaternary. After [43, 33, 34, 35, 47]. 
Based on the regional geological sections and available oil well data, potential $\mathrm{CO}_{2}$ storage sectors were searched in the Veracruz province. One of them is sector V2-5 in section V2. Sector V2-5 is characterized at 2450 meters depth by a lower Miocene terrigenous sequence that consists of interbedded green to gray bentonitic shale, layers of bentonite, coarse grained to conglomeratic sandstone, and conglomerate composed by fragments of gray to dark grayish brown clayey limestone and light brown bioclastic limestone [40, 43].

The conglomerate and the sandstone horizons were interpreted as potential formations to store $\mathrm{CO}_{2}$. So, at the top of the lower Miocene sequence is a 50 meters thick horizon that is part of an anticline. It is overlain by homogeneous greenish gray shale interpreted as a good seal cap rock (Figure 18).

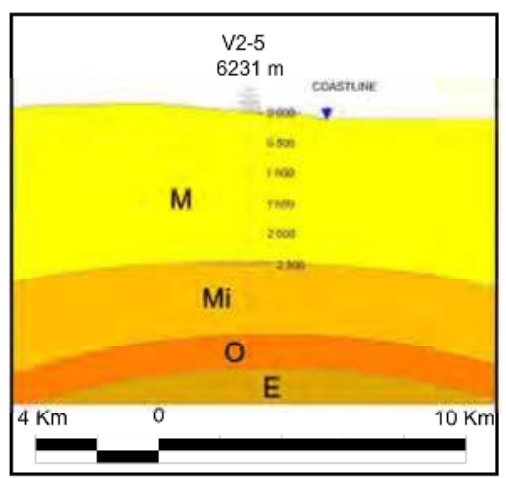

Fig. 18. Sector V2-5 showing a stratigraphic trap at the top of an anticline structure. Vertical scale is in meters. E: Eocene, O: Oligocene, Mi: Lower Miocene, M: Miocene, Q: Quaternary.

The horizon presents the following petrophysical properties, net thickness 15 meters, porosity 0.15 , irreducible water 0.15 , and permeability $200 \mathrm{mD}$. The assumed $\mathrm{CO}_{2}$ density for that depth of storage was $700 \mathrm{Kg} / \mathrm{m}^{3}$. The use of these parameters in the theoretical calculation of the capacity resulted in $0.03 \mathrm{Gt}$ (Table 7).

\begin{tabular}{|r|r|r|r|}
\hline \multicolumn{4}{|c|}{$\mathrm{CO}_{2}$ THEORETICAL STORAGE CAPACITY IN SECTOR V2-5 } \\
\hline Total thickness & & 50 & $\mathrm{~m}$ \\
\hline Net fraction & & 0.3 & $\mathrm{~m}$ \\
\hline Net thickness & & 15 & $\mathrm{~m}$ \\
\hline Cross section length & & 2500 & $\mathrm{~m}$ \\
\hline Length influence & & 10000 & $\mathrm{~m}$ \\
\hline Area & $\mathrm{A}$ & 25000000 & $\mathrm{~m}^{2}$ \\
\hline Volume & $\mathrm{V}$ & 375000000 & $\mathrm{~m}^{3}$ \\
\hline Porosity & $\Phi$ & 0.15 & \\
\hline Irreducible water saturation & $\mathrm{S}_{\text {wirr }}$ & 0.15 & \\
\hline $\mathrm{CO}_{2}$ Density & $\rho_{\mathrm{CO}}$ & 700 & $\mathrm{~kg}_{2} / \mathrm{m}^{3}$ \\
\hline Storage capacity in volume unit & $\mathrm{V}_{\mathrm{CO} 2 \mathrm{t}}$ & 47812500.00 & $\mathrm{~m}^{3} \mathrm{CO}_{2}$ \\
\hline Storage capacity in terms of mass & $\mathrm{MCO}_{2} \mathrm{t}$ & 0.03 & $\mathrm{Gt} \mathrm{CO}_{2}$ \\
\hline
\end{tabular}

Table 7. Theoretical storage capacity at Sector V2-5 in the Veracruz province. 
According to the theoretical calculations carried out in the Veracruz province resulted 21 sectors with $\mathrm{CO}_{2}$ capacity potential (Figure 19). Five of the sectors correspond to carbonate sequences, and the remaining 16 are terrigenous sequences. The estimated capacity targets reach $15.23 \mathrm{Gt}$ (Table 8).

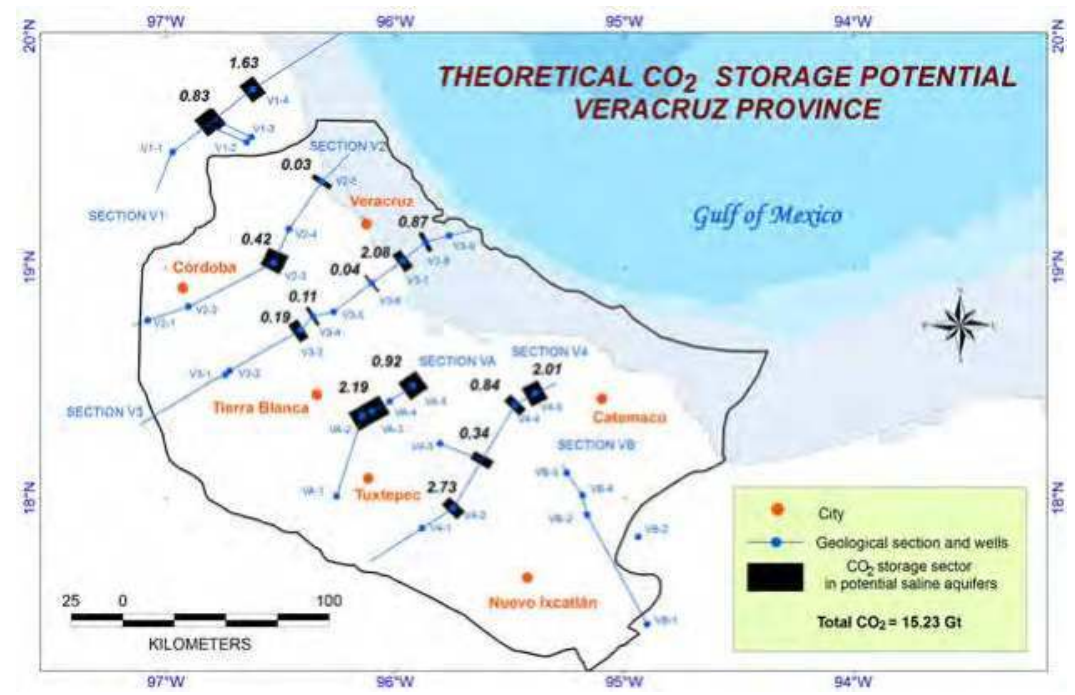

Fig. 19. Sectors with $\mathrm{CO}_{2}$ storage potential in saline aquifers at the Veracruz province.

\subsection{Sureste province}

The Sureste province is situated in the southeastern region of Mexico on the southern edge of the Gulf of Mexico. This province is bordered to the south by the Sierra de Chiapas mountainous range, to the east by the Yucatan Peninsula, to the west by the Veracruz province, and to the north and northeast by the Gulf of Mexico. The Sureste province comprises both mainland and offshore areas. In mainland the extensive geological exposures show evidence of the last episode of sedimentary infilling, therefore, most of the area is covered mainly by late Cenozoic sedimentary deposits (Figure 20).

The internal subsurface configuration of the province is characterized by very deep and fragmented basement affected by different tectonic deformational events. At depth the Sureste province is divided into four subprovinces: Salina del Istmo, Comalcalco, Reforma-Akal and Macuspana [40, 44, 45]. The basement of the province consists of crystalline rocks of Precambrian and Paleozoic age [30,49] most of which are covered by Mesozoic rock units composed of red beds, marine evaporites and carbonates of basin and platform marine facies [53]. Overlying the Mesozoic rocks are Paleogene terrigenous deposits of deep and shallow marine, deltaic, lagoonal and even alluvial facies [51, 52]. In addition, there are terrigenous sequences belonging to deltaic, lagoonal and shallow marine sedimentary facies that cover all the earlier deposits [40, 52, 54].

Six regional geologic cross sections (SE1, SE2, SE3, SE4, SE5 and SE6) were analyzed in order to estimate theoretical $\mathrm{CO}_{2}$ potential capacity in the province. The regional cross sections show that the sedimentary sequences from Jurassic to Oligocene-Lower Miocene were 
folded and reversely faulted. Also, it is evident that the younger late Cenozoic terrigenous sequences were faulted, but this time, under an extensional tectonic regime. The entire province was first under contractional tectonic regimes, and then it was affected by extensional tectonic events during erosion-sedimentation stages.The position of the Sureste province could be viewed in terms of the jointly evolution of a passive continental margin associated to a strike-slip and a subduction margins both related to the plate tectonic interaction at the pacific region of Mexico. However, the complete and detailed tectonic history of the province is not yet well known. The subsurface stratigraphical and structural complexity is shown in Section SE2 which is approximately 135 kilometers long, is located in the middle of the province, and is running along a northwest-southeast line (Figure 21).

\begin{tabular}{|c|c|c|c|c|c|c|c|c|c|c|c|}
\hline \multicolumn{12}{|c|}{ VERACRUZ PROVINCE } \\
\hline \multirow{2}{*}{$\begin{array}{c}\text { CROSS } \\
\text { SECTI- } \\
\text { ON }\end{array}$} & \multirow[t]{2}{*}{$\begin{array}{l}\text { SEC- } \\
\text { TOR }\end{array}$} & \multirow[t]{2}{*}{$\begin{array}{c}\text { TRAP } \\
(*)\end{array}$} & \multicolumn{2}{|c|}{$\begin{array}{c}\text { TARGET } \\
\text { SEQUENCE }\end{array}$} & \multicolumn{2}{|c|}{ SIZE } & \multicolumn{4}{|c|}{$\begin{array}{c}\text { GENERAL PETROPHYSICAL } \\
\text { PARAMETERS }\end{array}$} & \multirow{2}{*}{$\begin{array}{c}\text { Partial } \\
\text { capacity } \\
\text { in terms } \\
\text { of mass } \\
(\mathrm{Gt})\end{array}$} \\
\hline & & & $\begin{array}{c}\text { Terrige- } \\
\text { nous }\end{array}$ & $\begin{array}{c}\text { Carbon- } \\
\text { ate }\end{array}$ & $\begin{array}{c}\text { Area } \\
\left(10^{6} \mathrm{~m}^{2}\right)\end{array}$ & $\begin{array}{c}\text { Thick- } \\
\text { ness } \\
(\mathrm{m})\end{array}$ & $\begin{array}{c}\text { Effe- } \\
\text { ctive } \\
\text { porosi- } \\
\text { ty }\left(\Phi_{e}\right)\end{array}$ & \begin{tabular}{|c|} 
Irredu- \\
cible \\
water \\
sat. $\left(S_{\text {wirr }}\right)$
\end{tabular} & \begin{tabular}{|c|}
$\mathrm{CO}_{2}$ \\
Dens-ity \\
$(\mathrm{Kg} /$ \\
$\left.\mathrm{m}^{3}\right)$
\end{tabular} & \begin{tabular}{|c|} 
Perme- \\
ability \\
(mili- \\
darcies)
\end{tabular} & \\
\hline \multirow[t]{3}{*}{ V1 } & V1-3 & Strat & & $\mathrm{Kmp}$ & 52.7 & 202.5 & 0.1 & 0.04 & 700 & $<700$ & 0.72 \\
\hline & V1-3 & Strat & $\mathrm{P}$ & & 94.5 & 17.4 & 0.14 & 0.3 & 700 & $<60$ & 0.11 \\
\hline & V1-4 & Strat & $\bar{E}$ & & 78.15 & 285 & 0.15 & 0.25 & 650 & $<70$ & 1.63 \\
\hline \multirow[t]{4}{*}{ V2 } & V2-3 & Struct & & $\mathrm{Kmp}$ & 17 & 27 & 0.07 & 0.04 & 700 & $<600$ & 0.02 \\
\hline & V2-3 & Strat & & Ksp & 56 & 387 & 0.03 & 0.7 & 700 & $<200$ & 0.14 \\
\hline & V2-3 & Strat & $\mathrm{P}$ & & 56 & 86.46 & 0.15 & 0.35 & 550 & $<40$ & 0.26 \\
\hline & $\mathrm{V} 2-5$ & Struct & $\mathrm{Mi}$ & & 25 & 15 & 0.15 & 0.15 & 700 & $<200$ & 0.03 \\
\hline \multirow[t]{6}{*}{ V3 } & V3-3 & Struct & & $\mathrm{Kmp}$ & 26.3 & 10 & 0.07 & 0.2 & 700 & $<300$ & 0.01 \\
\hline & V3-3 & Strat & & Ksp & 43.6 & 147.2 & 0.08 & 0.4 & 600 & $<200$ & 0.18 \\
\hline & V3-4 & Strat & $\mathrm{Mi}$ & & 16 & 104 & 0.12 & 0.18 & 700 & $<300$ & 0.11 \\
\hline & V3-6 & Struct & Mi & & 10.4 & 54.9 & 0.12 & 0.18 & 700 & $<300$ & 0.04 \\
\hline & V3-7 & Struct & $\mathrm{Mi}$ & & 46 & 723.75 & 0.12 & 0.2 & 650 & $<300$ & 2.08 \\
\hline & V3-8 & Struct & $\mathrm{Mi}$ & & 21.65 & 698 & 0.12 & 0.2 & 600 & $<300$ & 0.87 \\
\hline \multirow[t]{4}{*}{$\mathrm{V} 4$} & V4-2 & Strat & $\mathrm{Mi}$ & & 76.9 & 312 & 0.25 & 0.3 & 650 & $<80$ & 2.73 \\
\hline & V4-3 & Struct & $\mathrm{Mi}$ & & 43.75 & 115 & 0.12 & 0.2 & 700 & $<200$ & 0.34 \\
\hline & V4-4 & Struct & Mi & & 43.6 & 280 & 0.12 & 0.18 & 700 & $<300$ & 0.84 \\
\hline & V4-5 & Struct & $\mathrm{Mi}$ & & 83.7 & 348 & 0.12 & 0.18 & 700 & $<300$ & 2.01 \\
\hline \multirow[t]{4}{*}{ VA } & VA-2 & - & $\mathrm{P}$ & & 50 & 12 & 0.25 & 0.3 & 700 & $<20$ & 0.07 \\
\hline & VA-3 & - & $\mathrm{Mi}$ & & 100 & 75 & 0.12 & 0.1 & 700 & $<300$ & 0.57 \\
\hline & VA-3 & - & E & & 100 & 138 & 0.2 & 0.2 & 700 & $<50$ & 1.55 \\
\hline & VA-5 & - & Mi & & 100 & 133.5 & 0.12 & 0.18 & 700 & $<300$ & 0.92 \\
\hline \multicolumn{10}{|c|}{ 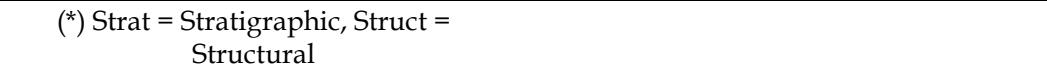 } & TOTAL & 15.23 \\
\hline
\end{tabular}

Table 8. Theoretical storage capacity of the Veracruz province. 


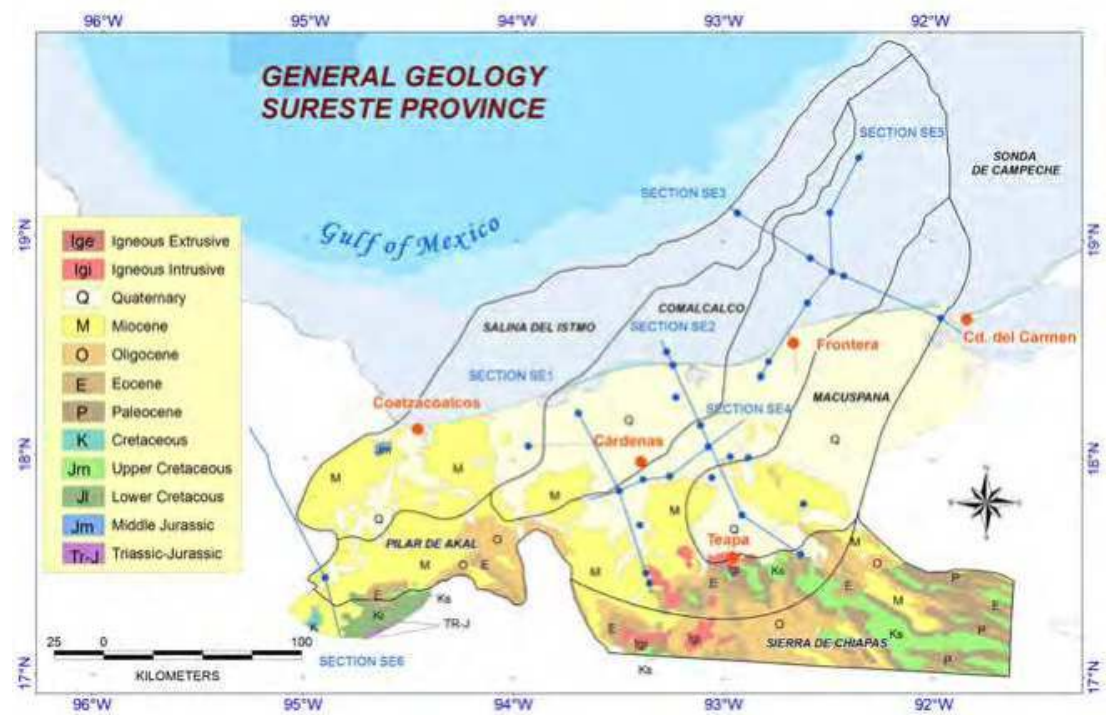

Fig. 20. Simplified geologic map of the Sureste province. It shows the location of regional geologic sections, wells, and limits of subprovinces: Salina del Istmo, Comalcalco, Macuspana and Pilar de Akal. After [33, 34, 35, 41, 44, 45, 46].

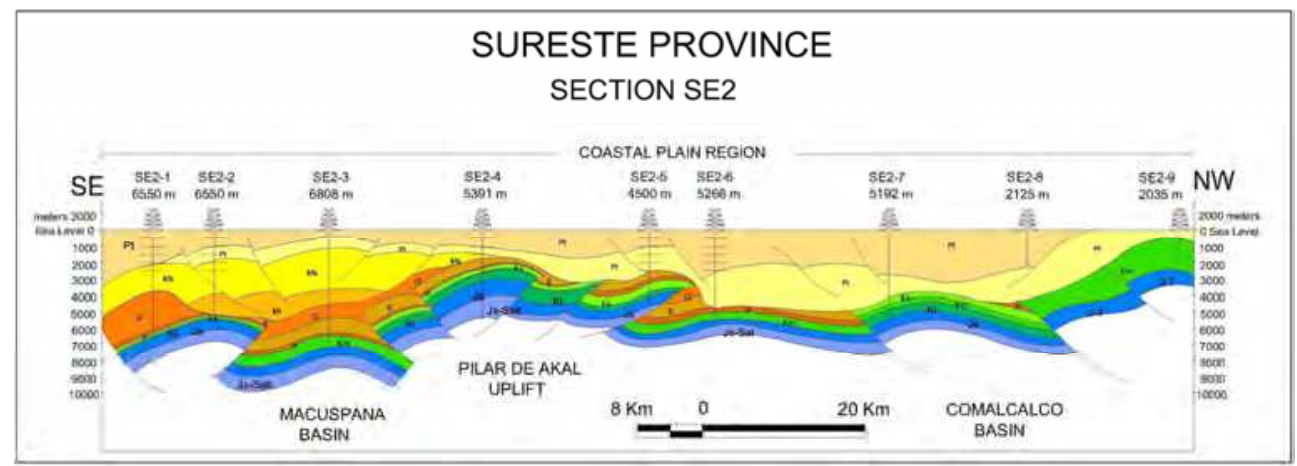

Fig. 21. Regional cross section SE3 depicting complex tectonic deformation in the Sureste province. Js: Upper Jurassic, Ki: Lower Cretaceous, Km: Middle Cretaceous, Ks: Upper Cretaceous, P: Paleocene, E: Eocene, O: Oligocene, Mi: Lower Miocene, Ms: Upper Miocene, Pl: Pliocene, Pt: Pleistocene, Q: Quaternary. After [34, 35, 40, 51].

Section SE2 traverses the Comalcalco, Macuspana and Reforma-Akal uplift subprovinces. The Comalcalco and Macuspana are sedimentary basins separated in turn by the ReformaAkal uplift. In the three subprovinces there are from Jurassic through Oligocene folded and reverse faulted sedimentary sequences. At the Macuspana basin there are Miocene terrigenous sequences affected by both steep and gently dipping normal faults. In contrast, these terrigenous sediments are non-existent at the Comalcalco basin, therefore indicating 
synchronous erosion and sedimentation processes. At the Comalcalco basin the Pliocene and Plesitocene sediments can reach up to five kilometers in thickness, and the regularly spaced faults do not meet at the surface. All along the cross section is evident that the development of the basins is linked to the widespread fault systems and to subsidence mechanisms.

During the screening and selection of the sectors to estimate the $\mathrm{CO}_{2}$ capacity, several stratigraphic and anticline traps structures were found. One of them is presented in figure 22 to illustrate the procedure. The sector SE2-4 consists of an anticline structure verging in northeast direction with an average axis orientation of $\mathrm{N} 300^{\circ}$. The anticline includes rock units from Jurassic to Oligocene times that are marked first by reverse faulting episode, and then by a regional unconformity. The unconformity is overlain by Miocene and Pliocene rock units.

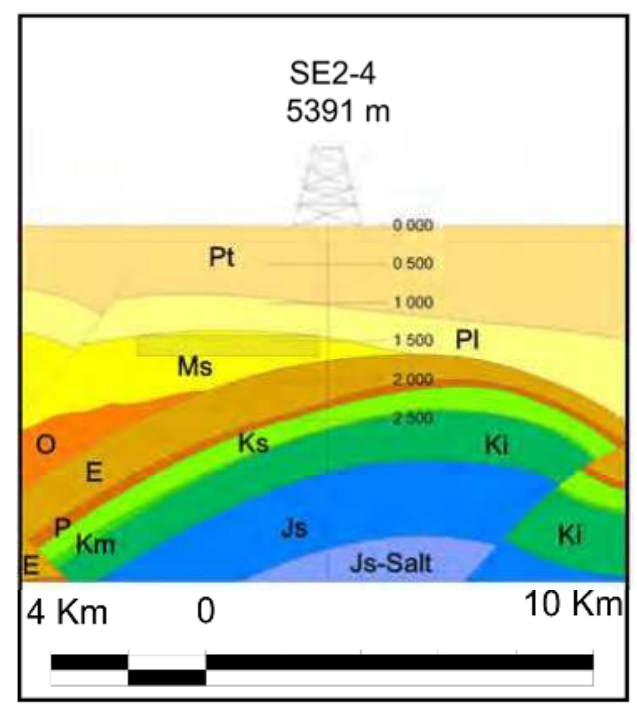

Fig. 22. Sector SE2-4 showing the location of the $\mathrm{CO}_{2}$ storage target in cross section SE2 of the Sureste province. Vertical scale in meters. Js: Upper Jurassic, Ki: Lower Cretaceous, Km: Middle Cretaceous, Ks: Upper Cretaceous, P: Paleocene, E: Eocene, O: Oligocene, Ms: Upper Miocene, Pl: Pliocene, Pt: Pleistocene.

The $\mathrm{CO}_{2}$ storage target is in a wedge of late Miocene well-bedded sequence about 280 meters thick and located 1550 meters deep. The storage sequence consists of a light gray, medium to coarse-grained, medium-bedded sandstone interbedded with occasional graygreenish shale containing mollusks and lignite fragments. The sandstone is overlain by a wide package of greenish gray shale of Pliocene age and interpreted as the seal layer. The petrophysical parameters of the sandstone target sequence are net thickness about 240 meters, clay content less than $4 \%$, porosity $\left(\Phi_{\mathrm{e}}\right)$ about $30 \%$, irreducible water saturation $\left(\mathrm{S}_{\text {wirr }}\right)$ less than $20 \%$ and permeability about 60 miliDarcys $(\mathrm{mD})$ (Table 9$)$. According to the 1550 meters sandstone depth where the $\mathrm{CO}_{2}$ density is approximately $681 \mathrm{Kg} / \mathrm{m}^{3}$, the theoretical storage capacity is close to $1.84 \mathrm{Gt}$ (million tons of $\mathrm{CO}_{2}$ ). 


\begin{tabular}{|r|r|r|r|}
\hline \multicolumn{4}{|c|}{$\mathrm{CO}_{2}$ THEORETICAL STORAGE CAPACITY IN SECTOR SE2-4. } \\
\hline Total thickness & & 283 & $\mathrm{~m}$ \\
\hline Net fraction & & 0.85 & $\mathrm{~m}$ \\
\hline Net thickness & & 240.55 & $\mathrm{~m}$ \\
\hline Cross section length & & 4573.47 & $\mathrm{~m}$ \\
\hline Length influence & & 10000 & $\mathrm{~m}$ \\
\hline Area & $\mathrm{A}$ & 1100148.21 & $\mathrm{~m}^{2}$ \\
\hline Volume & $\mathrm{V}$ & 11001482085 & $\mathrm{~m}^{3}$ \\
\hline Porosity & $\Phi$ & 0.3 & \\
\hline Irreducible water saturation & Swirr & 0.18 & \\
\hline CO ${ }_{2}$ Density & $\rho C O 2$ & 681 & $\mathrm{~kg}^{3} \mathrm{~m}^{3}$ \\
\hline Storage capacity in volume unit & VCO2t & 2706364592.91 & $\mathrm{~m}^{3} \mathrm{CO}_{2}$ \\
\hline Storage capacity in terms of mass & MCO2t & 1.84 & $\mathrm{Gt} \mathrm{CO}_{2}$ \\
\hline
\end{tabular}

Table 9. Theoretical storage capacity at Sector SE2-4, in the Sureste province, is near 1.84 million tons of $\mathrm{CO}_{2}$.

On the basis of the estimations conducted in the Sureste province resulted 17 sectors with $\mathrm{CO}_{2}$ capacity potential (Figure 23). Six of them are within offshore subsurface lands. The total capacity estimate is around $24.10 \mathrm{Gt}$ on terrigenous sedimentary sequences (Table 10).

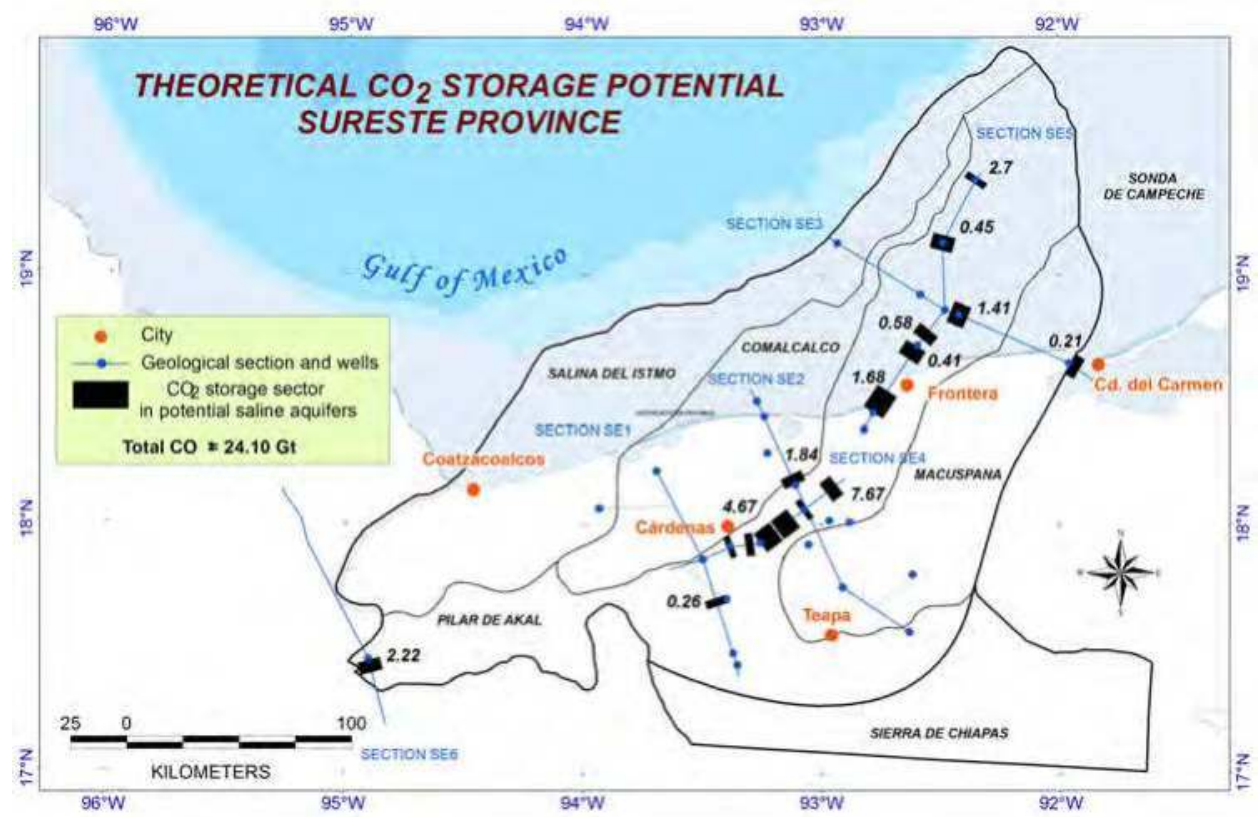

Fig. 23. Sectors shown in black with $\mathrm{CO}_{2}$ storage potential in saline aquifers at the Sureste province. 


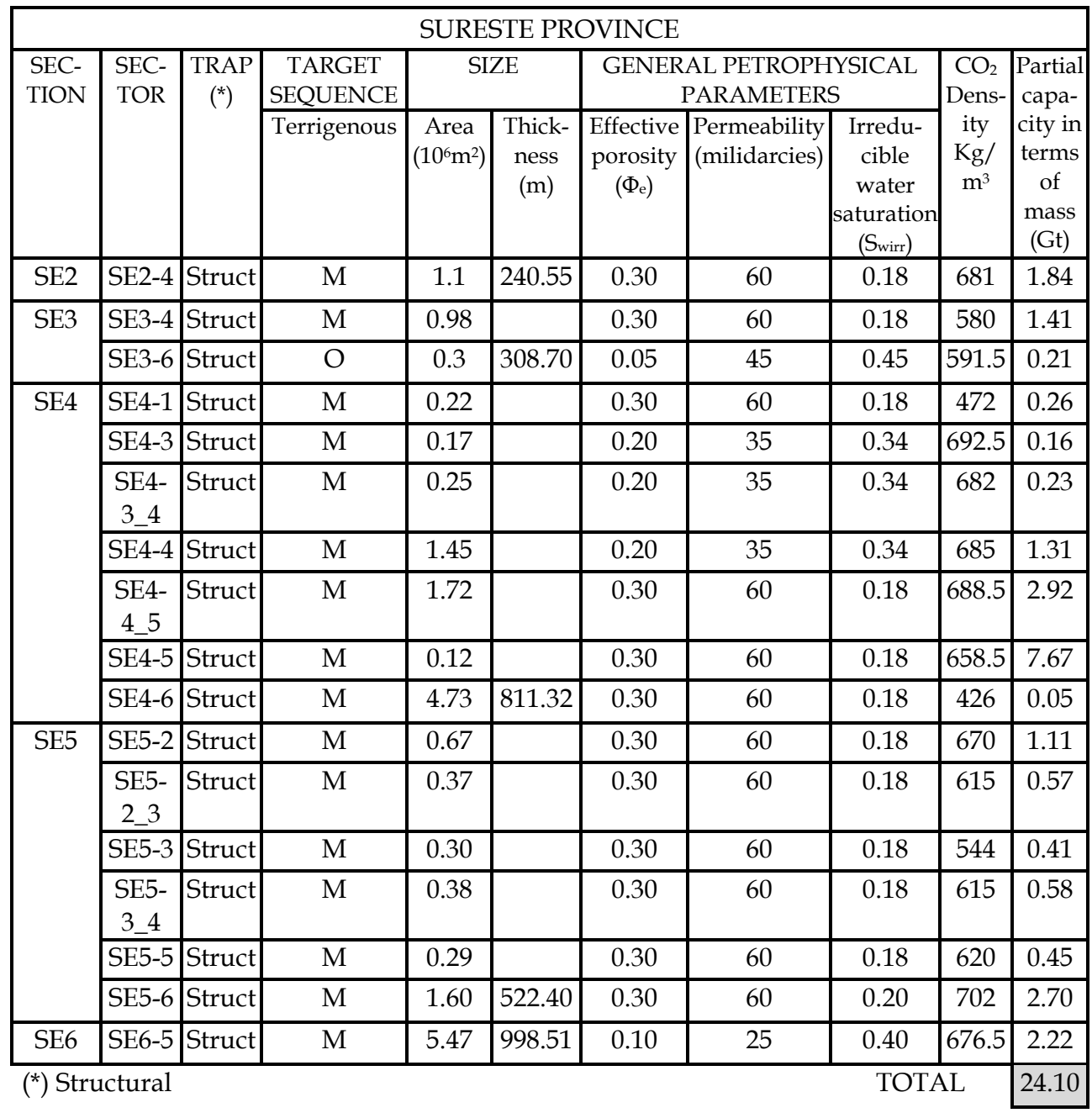

Table 10. Theoretical storage capacity of the Sureste province.

\subsection{Yucatan province}

The Yucatan province is bounded to the northeast by the Campeche Escarpment (which is formed on the edge of the marine continental shelf), to the east by the Caribbean Sea (where the marine platform is quite narrow), to the west by the Sonda de Campeche and to the south and southeast by the Sierra de Chiapas mountain ranges, Los Chuchumatanes Dome in Guatemala, and the Maya Mountains of Belize [43, 16, 55]. The area of study comprises the onshore portion known as Yucatan Peninsula and some offshore submerged areas in the Sonda de Campeche and the Yucatan marine platform regions (Figure 24).

The geology of the province can be characterized in subsurface terms by a huge basement block composed of Paleozoic rocks [43]. This crustal tectonic element has been present since 
the origin of the Gulf of Mexico [56]. On top of the basement, Jurassic evaporites, Cretaceous carbonates, as well as both Tertiary carbonates and terrigenous sedimentary sequences were deposited [57, 38, 58]. The sedimentary sequences were not under intense tectonic stress since they show a nearly horizontal depositional pattern and some minor faults. However, at the surface level, the central part of the huge province presents normal faults of considerable length that could bear testimony of extensional tectonic events which affected Mesozoic and lower Tertiary rocks. Under this geological context, four long regional geologic cross sections were analyzed to estimate the $\mathrm{CO}_{2}$ storing capacity in the Yucatan Province.

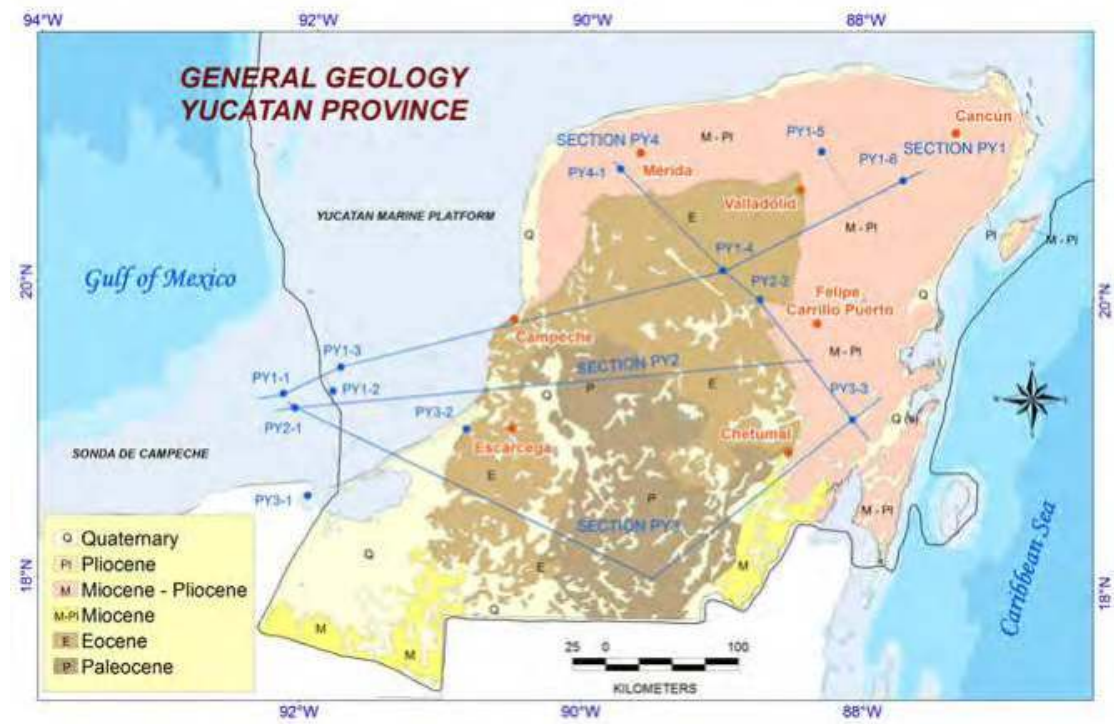

Fig. 24. Simplified geology map of Yucatan province showing regional geologic sections and wells. After $[40,43,34,35,33,55,63]$.

The Yucatan province exposes a very wide and nearly horizontal sedimentary Mesozoic and Cenozoic rock sequences, where the topographic elevations rarely exceeds 200 meters above sea level. Because of this quite regular geologic homogeneity it is believed that the Yucatan peninsula remained stable throughout its geologic history. In contrast, at the edge of the basement block in the Sonda de Campeche, the offshore submerged area display Miocene contractional and extensional tectonic deformations linked to the geologic evolution of the Sureste province [59, 60]. The regional cross section Y2, approximately $400 \mathrm{~km}$ in length, depicts geological features frequently found in the entire province. At the offshore area within the Sonda de Campeche region gently folds structures in Mesozoic and early Cenozoic strata indicate a tectonic regime not so intense. Later, Cenozoic sequences of rocks denote normal faults systems that affected almost the complete stratigraphic column (Figure 25).

Sector PY2-1 illustrates one of the selected potential sectors where saline aquifers could eventually become $\mathrm{CO}_{2}$ reservoirs. The Miocene terrigenous sequence is characterized by a thick succession of light colored sandstone interbedded with calcareous breccias and some layers of shale that alternate with calcareous arkoses lenses (Figure 26). Within the Miocene 
sequence, only the sandstone horizons were considered for the calculations of $\mathrm{CO}_{2}$ storage. The Miocene sequence is overlain by a thick package of Pliocene sediments composed of massive carbonaceous clay interbedded with peat layers and blue color clays. This package of sediments is interpreted as the seal rock unit.

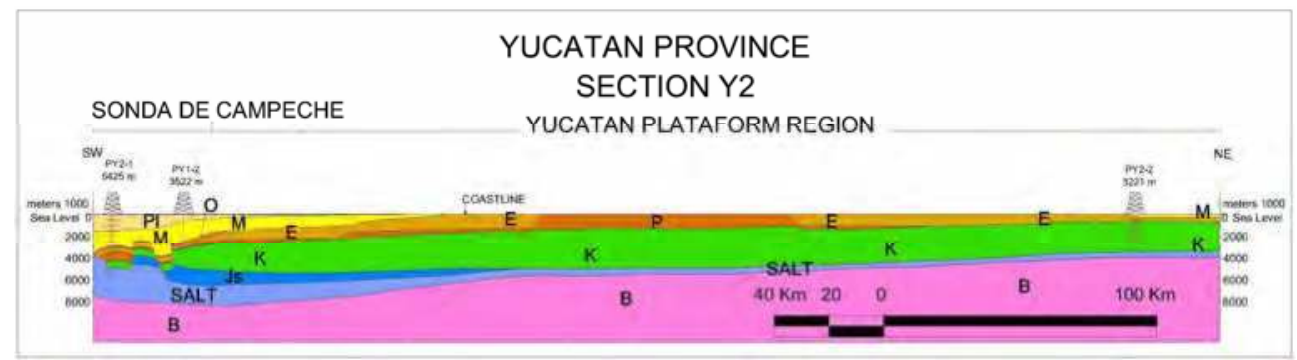

Fig. 25. Regional geological cross section Y2 showing Mesozoic sedimentary units gently deformed while the late Cenozoic sedimentary accumulations affected by extensional events within the offshore submerged region in the Sonda de Campeche. B: Basement, Js: Upper Jurassic, K: Cretaceous, P: Paleocene, E: Eocene, O: Oligocene, M: Miocene, Pl: Pliocene. After [34, 35, 33, 55].

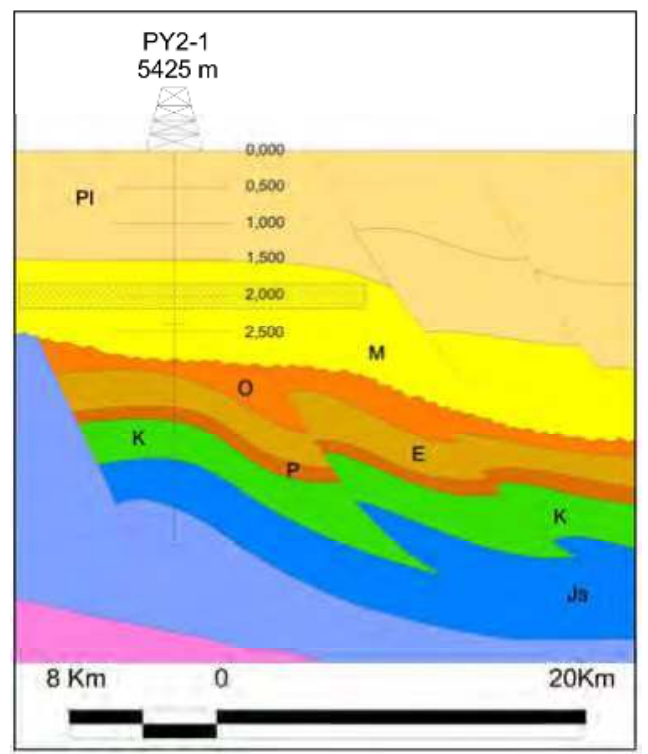

Fig. 26. Sector PY2-1 showing the location of the $\mathrm{CO}_{2}$ storage target. Vertical scale is in meters. Js: Upper Jurassic, K: Cretaceous, P: Paleocene, E: Eocene, O: Oligocene, M: Miocene, Pl: Pliocene.

The net thickness of the target sequence is about 353 meters with porosity $\left(\Phi_{e}\right)$ about $10 \%$ and irreducible water saturation $\left(\mathrm{S}_{\text {wirr }}\right) 30 \%$. Based on these parameters the theoretical capacity is $3.25 \mathrm{Gt}$ of $\mathrm{CO}_{2}$ in sector PY2-1(Table 11). 


\begin{tabular}{|r|r|r|r|}
\hline \multicolumn{5}{|c|}{$\mathrm{CO}_{2}$ THEORETICAL STORAGE CAPACITY IN SECTOR PY2-1 } \\
\hline Total thickness & & 884 & $\mathrm{~m}$ \\
\hline Net fraction & & 0.40 & $\mathrm{~m}$ \\
\hline Net thickness & & 353.60 & $\mathrm{~m}$ \\
\hline Cross section length & & 18793.18 & $\mathrm{~m}$ \\
\hline Length influence & & 10000 & $\mathrm{~m}$ \\
\hline Area & $\mathrm{A}$ & 6645268.45 & $\mathrm{~m}^{2}$ \\
\hline Volume & $\mathrm{V}$ & 66452684480 & $\mathrm{~m}^{3}$ \\
\hline Porosity & $\Phi$ & 0.10 & \\
\hline Irreducible water saturation & Swirr & 0.30 & \\
\hline CO ${ }_{2}$ Density & $\rho C O 2$ & 699.2 & $\mathrm{~kg}^{3} \mathrm{~m}^{3}$ \\
\hline Storage capacity in volume unit & VCO2t & 4651687913.60 & $\mathrm{~m}^{3} \mathrm{CO}_{2}$ \\
\hline Storage capacity in terms of mass & MCO2t & 3.25 & $\mathrm{Gt} \mathrm{CO}_{2}$ \\
\hline
\end{tabular}

Table 11. Theoretical storage capacity at Sector PY2-1 is near 3.25 million tons of $\mathrm{CO}_{2}$.

The analyses of the Yucatan province yield seven sectors capable of storing $\mathrm{CO}_{2}$ with a total theoretical capacity estimate of $14.44 \mathrm{Gt}$. Most of them are located in the offshore submerged lands of the Sonda de Campeche (Figure 27). The sectors are divided in terrigenous rock sequences with $10.46 \mathrm{Gt}$ and carbonate sequences with $3.98 \mathrm{Gt}$ (Table 12).

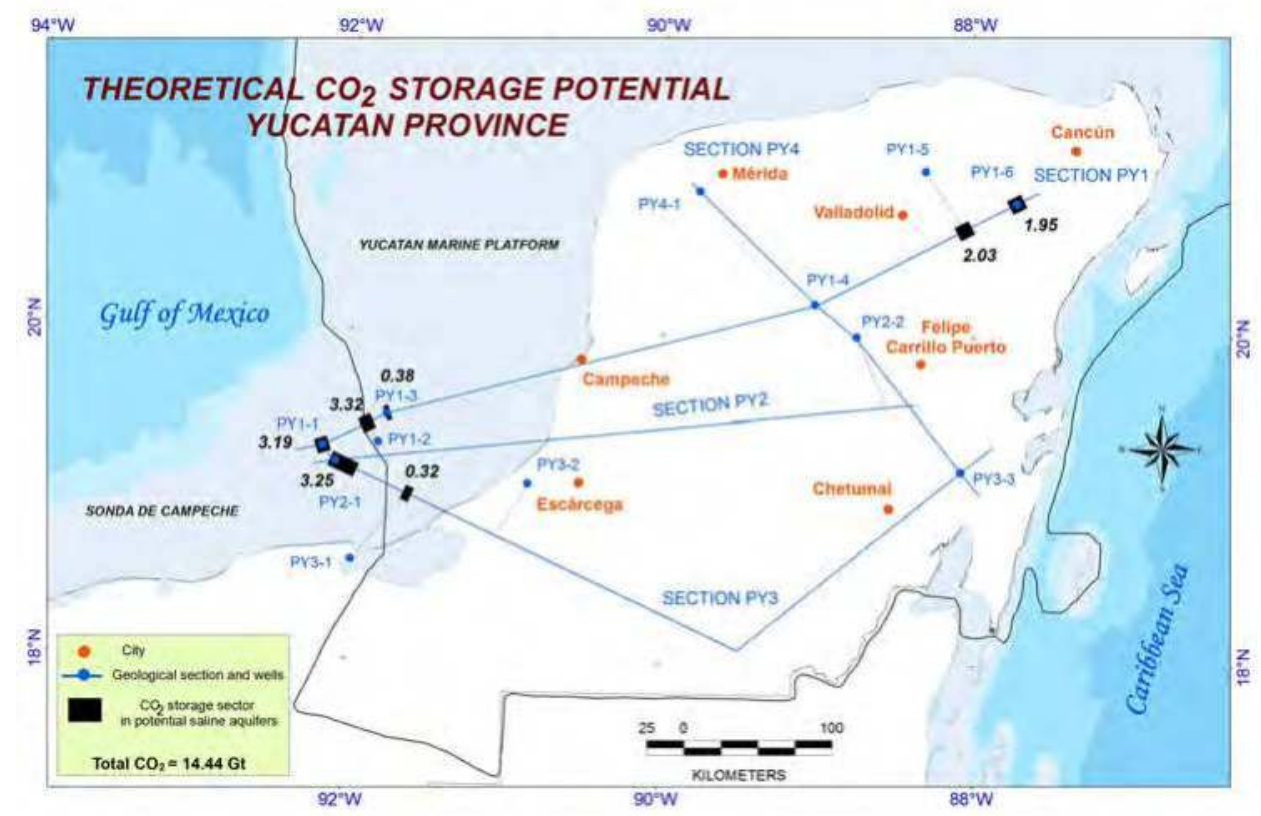

Fig. 27. Sectors (shown in black) with $\mathrm{CO}_{2}$ storage potential in saline aquifers, Yucatan province. 


\begin{tabular}{|c|c|c|c|c|c|c|c|c|c|c|c|}
\hline \multicolumn{12}{|c|}{ YUCATAN PROVINCE } \\
\hline \multirow{2}{*}{\begin{tabular}{|l|} 
CROSS \\
SEC- \\
TION
\end{tabular}} & \multirow[t]{2}{*}{\begin{tabular}{|l} 
SEC- \\
TOR
\end{tabular}} & \multirow[t]{2}{*}{\begin{tabular}{|c|} 
TRAP \\
$(*)$
\end{tabular}} & \multicolumn{2}{|c|}{$\begin{array}{c}\text { TARGET } \\
\text { SEQUENCE }\end{array}$} & \multicolumn{2}{|c|}{ SIZE } & \multicolumn{3}{|c|}{$\begin{array}{c}\text { GENERAL PETROPHYSICAL } \\
\text { PARAMETERS }\end{array}$} & \multirow{2}{*}{$\begin{array}{c}\mathrm{CO}_{2} \\
\text { Den- } \\
\text { sity } \\
(\mathrm{Kg} / \\
\left.\mathrm{m}^{3}\right)\end{array}$} & \multirow{2}{*}{$\begin{array}{l}\text { Partial } \\
\text { capa- } \\
\text { city in } \\
\text { terms } \\
\text { of } \\
\text { mass } \\
(\mathrm{Gt})\end{array}$} \\
\hline & & & $\begin{array}{l}\text { Terri- } \\
\text { genous }\end{array}$ & $\begin{array}{l}\text { Carbo- } \\
\text { nate }\end{array}$ & $\begin{array}{l}\text { Area } \\
\left(10^{6}\right. \\
\left.\mathrm{m}^{2}\right)\end{array}$ & $\begin{array}{c}\text { Thick- } \\
\text { ness } \\
\text { (m) }\end{array}$ & $\begin{array}{c}\begin{array}{c}\text { Effective } \\
\text { porosity } \\
\left(\Phi_{\mathrm{e}}\right)\end{array}\end{array}$ & $\begin{array}{l}\text { Perme- } \\
\text { ability } \\
\text { (mili- } \\
\text { darcies) }\end{array}$ & $\begin{array}{c}\text { Irreducible } \\
\text { water } \\
\text { saturation } \\
\left(S_{\text {wirr }}\right)\end{array}$ & & \\
\hline \multirow[t]{5}{*}{ PY1 } & PY1-1 & Strat & $\mathrm{M}$ & & 6.6 & 760 & 0.10 & 30 & 0.30 & 692 & 3.19 \\
\hline & PY1-2 & Strat & $\bar{M}$ & & 7.2 & 837 & 0.10 & 30 & 0.30 & 653 & 3.32 \\
\hline & PY1-3 & Strat & $\bar{M}$ & & 9.5 & 283.12 & 0.10 & 30 & 0.30 & 575 & 0.38 \\
\hline & PY1-5 & Strat & & $\overline{\mathrm{K}}$ & 3.3 & 320 & 0.10 & 200 & 0.13 & 702 & 2.03 \\
\hline & PY1-6 & Strat & & $\bar{K}$ & 3.2 & 308 & 0.10 & 200 & 0.13 & 701.5 & 1.95 \\
\hline \multirow[t]{2}{*}{ PY3 } & PY2-1 & Strat & $\bar{M}$ & & 6.6 & 353.60 & 0.10 & 30 & 0.30 & 699.2 & 3.25 \\
\hline & PY3-1 & Strat & $\overline{\mathrm{M}}$ & & 0.65 & & 0.10 & 30 & 0.30 & 691.5 & 0.32 \\
\hline \multicolumn{10}{|c|}{$\left(^{*}\right)$ Stratigraphic } & $\begin{array}{c}\text { TOTA } \\
\text { L }\end{array}$ & 14.44 \\
\hline
\end{tabular}

Table 12. Theoretical storage capacity in Yucatan province is 14.44 million tons of $\mathrm{CO}_{2}$.

In summary, the theoretical $\mathrm{CO}_{2}$ capacity estimates in Mexico stands currently at $81.59 \mathrm{Gt}$ on terrigenous and calcareous sequences located within the outlined inclusion zones. The total assessed sectors are 88 with possibilities of $\mathrm{CO}_{2}$ storage in potential saline aquifers (Table 13). The assessed sectors in terrigenous sedimentary sequences are 77 while in carbonate sequences are 11 .

\begin{tabular}{|c|c|c|}
\hline PROVINCE & $\begin{array}{c}\text { THEORETICAL CO } \\
\text { STORAGE POTENCIAL (Gt) }\end{array}$ & $\begin{array}{c}\text { SECTORS } \\
\text { ASSESSED }\end{array}$ \\
\hline Burgos & 17.81 & 31 \\
\hline Tampico-Misantla & 10.01 & 12 \\
\hline Veracruz & 15.23 & 21 \\
\hline Sureste & 24.10 & 17 \\
\hline Yucatan & 14.44 & 7 \\
\hline TOTAL & 81.59 & 88 \\
\hline
\end{tabular}

Table 13. Summary of theoretical storage potential in saline aquifers of Mexico.

\section{Conclusions}

In Mexico the energy sector is responsible of more than $70 \%$ of the carbon dioxide emissions. In order to address the possibility of storing such anthropogenic $\mathrm{CO}_{2}$ in deep underground geologic formations three lines of analysis were performed. First, the type, location and magnitude of $\mathrm{CO}_{2}$ sources indicate approximately $216 \mathrm{Gt}$ of $\mathrm{CO}_{2}$ emissions coming from 1860 point sources. Second, five out of twelve geological provinces were analyzed. The assessed provinces are Burgos, Tampico-Misantla, Veracruz, Sureste and 
Yucatan which have the best favorable conditions for underground $\mathrm{CO}_{2}$ storage in sedimentary rock successions of Mesozoic and Tertiary age. They are geologically well defined and located within the coastal plain region around the western portion of Gulf of Mexico. Third, theoretical storage capacities in potential saline aquifers sectors were estimated for each geological province. The theoretical $\mathrm{CO}_{2}$ storage estimates and the number of assessed sectors are: Burgos province $17.81 \mathrm{Gt}$ in 31 sectors, Tampico-Misantla province $10.01 \mathrm{Gt}$ in 12 sectors, Veracruz province $15.23 \mathrm{Gt} 21$ sector, Sureste $24.10 \mathrm{Gt}$ in 17 sectors and Yucatan province $14.44 \mathrm{Gt}$ in 7 sectors. The total theoretical $\mathrm{CO}_{2}$ storage potential currently stands at $81.59 \mathrm{Gt}$ within 88 assessed sectors for the entire nation. During the $\mathrm{CO}_{2}$ storage capacity estimations, it became clear that some areas yielded more and better quality data than others. Therefore, it is acknowledged that these data sets are not complete. However, it is anticipated that $\mathrm{CO}_{2}$ storage capacity estimates, geological formation maps as well as regional geological cross sections will be updated as new information, particularly oil wells data, are acquired and methodologies for $\mathrm{CO}_{2}$ storage capacity estimates are improved in Mexico.

\section{References}

[1] M. Dávila, O. Jiménez, V. Arévalo, R. Castro and J. Stanley. “A preliminary selection of regions in Mexico with potential for geological carbon storage". International Journal of Physical Science, vol.5, num.5, pp.408-414, 2010.

[2] DOE (U.S. Departament of Energy). “2010 Carbon sequestration Atlas of the United States and Canada". Third edition, NETL (National Energy Technology Laboratory), 160p., 2011.

[3] RETC (Pollutant Release and Transfer Inventory) database. Secretaría del Medio Ambiente y Recursos Naturales, Mexico, Internal Report, 2008.

[4] SEMARNAT (Ministry of the Environment and Natural Resources). "Fourth National Communication to the United Nations Framework Convention on Climate Change (2006)". Instituto Nacional de Ecología, Mexico, 274p. Primera edición 2009. Available: http://www.ine.gob.mx.

[5] C.A. Hendricks and K. Blok. "Underground storage of carbon dioxide". Energy Convers Manage, vol.34, pp.949-957, 1993.

[6] S. Bachu."Sequestration of $\mathrm{CO}_{2}$ in geological media: criteria and approach for site selection in response to climate change". Energy Convers Manage, vol. 41, pp. 953-970, 2000.

[7] J. Bradshaw J. and A. Rigg. "The GEODETIC Program: research into geological sequestration of $\mathrm{CO}_{2}$ in Australia". Environmental Geosciences, vol. 8, pp. 166-176, 2001.

[8] S. Bachu and S. Stewart. "Geological sequestration of anthropogenic carbon dioxide in the Western Canada sedimentary basin: suitability analysis". Canadian Journal of Petroleum Technology, vol. 41, num.2, pp.32-40, 2002.

[9] S. Bachu. "Screening and ranking of sedimentary basins for sequestration of $\mathrm{CO}_{2}$ in geological media in response to climate change". Environmental Geology, vol. 44,pp.277-289, 2003.

[10] S. Bachu, D. Bonijoly, J. Bradshaw, R. Burruss, S. Holloway, N.P. Christensen, and M. Mathiassen. " $\mathrm{CO}_{2}$ storage capacity estimation: methodology and gaps". International Journal Greenhouse Gas Control, vol.1, pp. 430-443, 2007.

[11] S. Bachu. " $\mathrm{CO}_{2}$ storage in geological media: role, means, status and barriers to deployment". Progress Energy Combustion Science, vol. 34, pp. 254-273, 2008. 
[12] A.W. Bally."Musings over sedimentary basin evolution". Philosophical Transactions of the Royal Society of London, vol. 305, pp. 325-338, 1982.

[13] R. Ingersoll "Tectonics of sedimentary basins". Geological Society of America Bulletin, vol. 100, pp. 1704-1719, 1988.

[14] Y.L. Leonov and Y.A. Voloz. Sedimentary basins: study methods, structure and evolution. Nauchnyi Mir, 525p., 2004.

[15] Ch. French and Ch. Schenk (compilers). "Map showing geology, oil and gas fields, and geologic provinces of the Gulf of Mexico Region". USGS Open-File Report 97-470L, 1997.

[16] PEMEX (Petróleos Mexicanos). “Provincias petroleras de México". Pemex Exploración y Producción, México, Versión 1.0, 11p., 2010.

[17] F. Campa and P. Coney."Tectonostratigraphic terranes and mineral resource distribution in Mexico". Canadian Journal of Earth Sciences, vol.20,pp.1040-1051, 1983.

[18] F. Ortega, L. Mitre, J. Roldán, J. Aranda, D. Morán, S. Alaníz, A. Nieto. “Texto Explicativo de la Quinta Edición de la Carta Geológica de la República Mexicana, Escala 1:2`000,000”. Instituto de Geología, UNAM-Consejo de Recursos Minerales, SEMIP, México, 1992.

[19] R. Sedlock, F. Ortega and R. Speed. "Tectonostratigraphic terranes and tectonic evolution of Mexico". Geological Society of America Special Paper 278, 153 p., 1994.

[20] J. Gale, N.P. Christensen, A. Cutler and T. Torpe. "Demonstrating the potential for geological storage of $\mathrm{CO}_{2}$ : The Sleipner and GESTCO project". Environmental Geosciences, vol.8, num.3, pp.160-165, 2001.

[21] R. Tarkowski, B. Uliasz, and A. Wojcicki. " $\mathrm{CO}_{2}$ storage capacity of deep aquifers and hydrocarbon fields in Poland”. Energy Procedia, vol.1, pp.2671-2677, 2009.

[22] J. Bradshaw, C. Boreham, and F. La Pedalina (2005). "Storage retention time of $\mathrm{CO}_{2}$ in sedimentary basins: examples from petroleum systems". Available: http:/ uregina.ca/ghgt7/PDF/papers/peer/427.pdf

[23] L.G.H. van der Meer and P.J. Egberts. "A general method for calculating subsurface $\mathrm{CO}_{2}$ storage capacity". Presented at the 2008 Offshore Technology Conference. OTC 19309, May 2008.

[24] S. Brennan and R. Burruss. "Specific Sequestration volumes: a useful tool for $\mathrm{CO}_{2}$ storage capacity assessment". USGS Open-File Report 03-452, 2009.

[25] S. Brennan, R. Burruss, M.D. Merrill, P.A. Freeman and L.F. Ruppert. "A probabilistic assessment methodology for the evaluation of geologic carbon dioxide storage". USGS Open-File Report 2010-1127, 31p., 2010.

[26] GCCSI (Global CCS Institute). "The status of CCS projects". Interim Report 2010, 26p., 2010. www.cslforum.org

[27] DOE (U.S. Department of Energy). “Best practices for: Geologic Storage Formation Classification: Understanding Its Importance and Impacts on CCS Opportunities in the United States". NETL (National Energy Technology Laboratory), 54p., 2010.

[28] DOE (U.S. Department of Energy). "2008 Carbon sequestration Atlas of the United States and Canada". 2nd edition. NETL (National Energy Technology Laboratory), 140p., 2008.

[29] E. López Ramos. Geologia de Mexico. Tomo II. Edicion Escolar: Mexico, 454 p., 1979.

[30] R.T. Buffler and D.S. Sawyer. "Distribution of crust and early history, Gulf of Mexico Basin". Gulf Coast Association Geological Societies Transactions,vol. 35, p.333-444, 1985.

[31] PEMEX (Petróleos Mexicanos). "La Provincia Petrolera Burgos". Pemex Exploración y Producción, México, Versión 1.0, 27p., 2010. 
[32] B. Ortiz."Interpretación estructural de una sección sísmica en la región ArcabuzCulebra de la Cuenca de Burgos, NE de México". Revista Mexicana de Ciencias Geológicas, vol. 21, num. 2, pp. 226-235, 2007.

[33] SGM (Servicio Geológico Mexicano) Cartas geológico mineras. Escala 1:250 000. Avaible: http:// mapasims.sgm.gob.mx:8399/mapasEnLinea/

[34] CFE (Comisión Federal de Electricidad ). "Integración de un Atlas de las principales cuencas sedimentarias de México". Technical Report. Convenio CFE-IPN-001/2009, enero 2010a.

[35] CFE (Comisión Federal de Electricidad ). "Geología del subsuelo de las principales zonas de las cuencas sedimentarias marinas y continentales alrededor del Golfo de México". Technical Report. Convenio CFE-IPN-001/2010, diciembre 2010b.

[36] E. Lopez-Ramos and J.C. Guerrero. "Paleogeografia y tectonica del Mesozoico de Mexico". Revista del Instituto de Geologia, vol. 5, pp. 158-177, 1981.

[37] PEMEX (Petróleos Mexicanos). "Provincia Petrolera Tampico Misantla". Pemex Exploración y Producción, Versión 1.0. 48 p. 2010.

[38] A Salvador. "Late Triassic-Jurassic Paleogeography and Origin of the Gulf of Mexico Basin". American Association of Petroleum Geologists Bulletin, vol.71, p.419-451, 1987.

[39] J.L. Pindell and J. F. Dewey. "Permo-Triassic reconstruction of western Pangea and the evolution of the Gulf of Mexico/Caribbean region". Tectonics, vol.1, p.179-211, 1982.

[40] J. Santiago, J. Carrillo and B. Martell. "Geología Petrolera de México". In: Evaluación de Formaciones en México, D. Marmissolle-Daguerre, Ed. Schlumberger, 1984, p. 1-36.

[41] INEGI (Instituto Nacional de Estadística, Geografía e Informática). “Atlas de Mapas Geológicos de Mexico". Ministry of Budget and Programming, Mexico, 1981.

[42] PEMEX (Petróleos Mexicanos). "Provincia petrolera Veracruz". Pemex Exploración y Producción, México, Versión 1.0, 38 p., 2010.

[43] E. López Ramos. Geologia de Mexico. Tomo III. Edicion Escolar: Mexico, 453 p., 1979.

[44] W.A. Ambrose, T.F. Wawrzyniec, K. Fouad, S.C. Talukdar, R.H. Jones, D.C. Jennette, M.H. Holtz, S. Sakurai, S.P. Dutton, D.B. Dunlap, E.H. Guevara, J. Meneses, J. Lugo, L. Aguilera, J. Berlanga, L. Miranda, J. Ruiz, R. Rojas and H. Solís. "Geologic framework of upper Miocene and Pliocene gas plays of the Macuspana Basin, Southeastern Mexico". American Association of Petroleum Geologists Bulletin, vol.87, num.9, pp.1411-1435, 2003.

[45] PEMEX (Petróleos Mexicanos). "Provincia Petrolera Golfo de México Profundo". Pemex Exploración y Producción, México, Versión 1.0, 26p., 2010.

[46] PEMEX (Petróleos Mexicanos). "Provincias Geológicas de México". Pemex Exploración y Producción, México, Versión 1.0, 18p., 2010.

[47] PEMEX (Petróleos Mexicanos). Provincia Petrolera Cinturón Plegado de la Sierra Madre Oriental. Pemex Exploración y Producción, Versión 1.0, 14 p., 2010.

[48] SPP (Secretaría de Programación y Presupuesto). "Atlas Nacional del Medio Físico". Secretaría de Programación y Presupuesto. Gobierno de México, 224 p., 1981.

[49] J.L. Pindell. "Alleghanian reconstruction and subsequent evolution of the Gulf of Mexico, Bahamas, and Proto-Caribbean". Tectonics, vol. 4, pp.1-39, 1985.

[50] J. L. Pindell and L. Kennan, "Rift models and the salt-cored marginal wedge in the northern Gulf of Mexico: implications for deep water Paleogene Wilcox deposition and basinwide maturation". In: Transactions of the 27th GCSSEPM Annual Bob F. Perkins Research Conference: The Paleogene of the Gulf of Mexico and Caribbean Basins: Processes, Events and Petroleum Systems. L. Kennan, J. L. Pindell and N. C. Rosen (eds), pp. 146-186, 2007. 
[51] F.J. Ángeles, N. Reyes, J.M. Quezada and J.R. Meneses. “Tectonic evolution, structural styles and oil habitat in the Campeche Sound, Mexico". Transactions of the Gulf Coast Associations of Geological Societies, vol. XLIV, pp.53-62, 1994.

[52] R. Padilla."Evolución geológica del sureste mexicano desde el Mesozoico al presente en el contexto regional del Golfo de México". Boletín de la Sociedad Geológica Mexicana, T. LIX, num.1, p.19-42, 2007.

[53] F.J. Angeles and A. Cantú, "Subsurface Upper Jurassic Stratigraphy in the Campeche Shelf, Gulf of Mexico". In: The Western Gulf of Mexico Basin: Tectonics, Sedimentary Basins, and Petroleum Systems. C. Bartolini, R.T. Buffler and A. Cantú (eds), American Association of Petroleum Geologists Memoir 75, 2001.

[54] J.Y. Narváez, J. Belenes, J. Moral, J.M. Martínez, C. Macías, O. Castillejos and M.A. Sánchez. "Bioestratigrafía de secuencias del Mioceno-Plioceno de la cuenca Macuspana, sureste del Golfo de México". Revista Mexicana de Ciencias Geológicas, vol.25, num.2, pp.217-224, 2008.

[55] PEMEX (Petróleos Mexicanos). "Provincia Petrolera Plataforma de Yucatán". Pemex Exploración y Producción, México, Versión 1.0, México, 17p., 2010.

[56] J. Pindell and L. Kennan. "Tectonic evolution of the Gulf of Mexico, Caribbean and northern South America in the mantle reference: an update". In The geology and evolution of the region between North and South America, K. James, M.A. Lorente and J. Pindell (eds), Geological Society of London Special Publication, 2009.

[57] M. Olivas. “Aspectos paleogeográficos de la región sureste de México en los estados de Veracruz, Tabasco, Chiapas, Campeche, Yucatán y el territorio de Quintana Roo". Boletín de la Asociación Mexicana de Geólogos Petroleros, vol. XXVI, num.10- 2, pp.323336, 1974.

[58] S. Medina. "Tertiary zonation based on planktonic foraminifera from the marine region of Campeche, Mexico". American Association of Petroleum Geologists, Memoir 75, pp.397-420, 2001.

[59] R. Sánchez, “Geología petrolera de la Sierra de Chiapas”. In: IX Excursión Geológica de Petróleos Mexicanos, Superintendencia General de Distritos de Exploración, Zona Sur, Libreto-Guía, 57 p. 1979.

[60] M. Guzmán and J. J. Meneses. “The North America-Caribbean plate boundary west of the Motagua-Polochic fault system: a fault jog in Southeastern Mexico". Journal of South American Earth Sciences, vol.13, num.4-5, pp., 2000.

[61] B. A. Méndez, "Geoquímica e isotopía de aguas de formación (salmueras petroleras) de campos mesozoicos de la Cuenca del Sureste de México: implicación en su origen, evolución e interacción agua-roca en yacimientos petroleros", Tesis Doctoral, Centro de Geociencias, UNAM, 200 p., 2007.

[62] R. K. Goldhammer and C. A. Johnson, "Middle Jurassic-Uper Cretaceous Paleogeographic evolution and sequence stratigraphic framework of the northwest Gulf of Mexico rim". In: The western Gulf of Mexico Basin: Tectonics, sedimentary basins and petroleum systems. C. Bartolini, T. Buffler, and A. Cantú (eds), American Association of Petroleum Geologists Memoir 75, p. 45-81, 2001.

[63] J.H. Rosenfeld. "Economic potential of the Yucatan block of Mexico, Guatemala, and Belize". In: The Circum-Gulf of Mexico and the Caribbean-Hydrocarbon habitats, basin formation, and plate tectonics: American Association of Petroleum Geologists Memoir 79, pp. 340-348, 2003.

[64] S. Angus, B. Armstrong and K.M. de Reuck. International Thermodynamic Tables of the Fluid State. Volume 3. Carbon Dioxide. Pergamon Press: IUPAC Division of Physical Chemistry, 1973, pp. 266-359. 


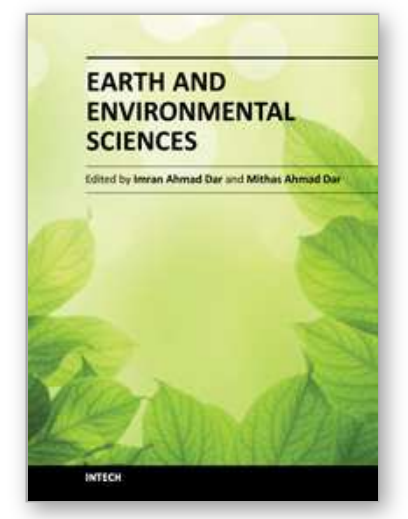

\author{
Earth and Environmental Sciences \\ Edited by Dr. Imran Ahmad Dar
}

ISBN 978-953-307-468-9

Hard cover, 630 pages

Publisher InTech

Published online 07, December, 2011

Published in print edition December, 2011

We are increasingly faced with environmental problems and required to make important decisions. In many cases an understanding of one or more geologic processes is essential to finding the appropriate solution. Earth and Environmental Sciences are by their very nature a dynamic field in which new issues continue to arise and old ones often evolve. The principal aim of this book is to present the reader with a broad overview of Earth and Environmental Sciences. Hopefully, this recent research will provide the reader with a useful foundation for discussing and evaluating specific environmental issues, as well as for developing ideas for problem solving. The book has been divided into nine sections; Geology, Geochemistry, Seismology, Hydrology, Hydrogeology, Mineralogy, Soil, Remote Sensing and Environmental Sciences.

\title{
How to reference
}

In order to correctly reference this scholarly work, feel free to copy and paste the following:

Oscar Jiménez, Moisés Dávila, Vicente Arévalo, Erik Medina and Reyna Castro (2011). Geological Carbon Dioxide Storage in Mexico: A First Approximation, Earth and Environmental Sciences, Dr. Imran Ahmad Dar (Ed.), ISBN: 978-953-307-468-9, InTech, Available from: http://www.intechopen.com/books/earth-andenvironmental-sciences/geological-carbon-dioxide-storage-in-mexico-a-first-approximation

\section{INTECH}

open science | open minds

\section{InTech Europe}

University Campus STeP Ri Slavka Krautzeka 83/A 51000 Rijeka, Croatia Phone: +385 (51) 770447 Fax: +385 (51) 686166 www.intechopen.com

\author{
InTech China \\ Unit 405, Office Block, Hotel Equatorial Shanghai \\ No.65, Yan An Road (West), Shanghai, 200040, China \\ 中国上海市延安西路65号上海国际贵都大饭店办公楼 405 单元 \\ Phone: +86-21-62489820 \\ Fax: +86-21-62489821
}


(C) 2011 The Author(s). Licensee IntechOpen. This is an open access article distributed under the terms of the Creative Commons Attribution 3.0 License, which permits unrestricted use, distribution, and reproduction in any medium, provided the original work is properly cited. 